\title{
Facies analysis and depositional model of the Serravallian-age Neurath Sand, Lower Rhine Basin (W Germany)
}

\author{
L. Prinz ${ }^{1, *}$, A. Schäfer ${ }^{1}$, T. McCann ${ }^{1}$, T. Utescher ${ }^{1,2}$, P. Lokay $^{3}$ \& S. Asmus $^{3}$
}

1 Steinmann Institute, Geology, University Bonn, Nussallee 8, 53115 Bonn, Germany

2 Senckenberg Research Institute, 60325 Frankfurt, Germany

3 RWE Power AG, Stüttgenweg 2, 50935 Köln, Germany

* Corresponding author. Email: lprinz@uni-bonn.de

Manuscript received: 8 December 2015, accepted: 5 December 2016

\section{Abstract}

The up to $60 \mathrm{~m}$ thick Neurath Sand (Serravallian, late middle Miocene) is one of several marine sands in the Lower Rhine Basin which were deposited as a result of North Sea transgressive activity in Cenozoic times. The shallow-marine Neurath Sand is well exposed in the Garzweiler open-cast mine, which is located in the centre of the Lower Rhine Basin. Detailed examination of three sediment profiles extending from the underlying Frimmersdorf Seam via the Neurath Sand and through to the overlying Garzweiler Seam, integrating both sedimentological and palaeontological data, has enabled the depositional setting of the area to be reconstructed.

Six subenvironments are recognised in the Neurath Sand, commencing with the upper shoreface (1) sediments characterised by glauconite-rich sands and an extensive biota (Ophiomorpha ichnosp.). These are associated with the silt-rich sands of a transitional subenvironment (2), containing Skolithos linearis, Planolites ichnosp. and Teichichnus ichnosp. These silt-rich sands grade up to the upper shoreface subenvironment (1), which is indicative of an initial regressive trend. The overlying intertidal deposits can be subdivided into a lower breaker zone (3), characterised by ridge-andrunnel systems, and the swash zone (4) where the surge and backwash of waves resulted in the deposition of high-energy laminites. The intertidal deposits were capped by aeolian backshore sediments (5). Extensive root traces present in this latter subenvironment reflect the development of the overlying peatland (i.e. Garzweiler Seam). Within the Garzweiler Seam, restricted sand lenses indicate a lagoonal or estuarine depositional environment (6). Regional correlation with adjacent wells establishes that shallow-marine conditions were widespread across the Lower Rhine Basin in middle Serravallian times. The shoreline profile, characterised by both tidal and wave activity and influenced by fluvial input from the adjacent Rhenish Massif, is indicative of the complexity of the coastal depositional setting within the Lower Rhine Basin.

Keywords: estuarine depositional environments, lignite, Neogene, shoreline

\section{Introduction}

The Lower Rhine Basin extends from NW Germany through to the SE Netherlands, and is an embayment (Lower Rhine Embayment) which formed as a result of basin subsidence and related marine transgressions in Oligocene times ( $R$. Teichmüller, 1958; Zagwijn \& Hager, 1987; Hager, 1993; Schäfer et al., 1996; Klett et al., 2002; Becker \& Asmus, 2005; Schäfer et al., 2005; Schäfer \& Utescher, 2014), and within which sub- to supratidal (Longhitano et al., 2012) sediments were deposited (Schäfer et al., 1996). The basin is a rift, extending into the Rhenish Massif and forming the NW part of the NW European Cenozoic Basin
(Ziegler, 1992, 1994; Houtgast \& van Balen, 2000; Klett et al., 2002; Sissingh, 2003; Ziegler \& Dèzes, 2007; Fig 1). During the late early and middle Miocene, warm temperate climate conditions in a highstand systems tract (but at a point where eustatic sea level had already begun to fall and the highstand system sediment surface was exposed, but immediately prior to the erosion surface marking the falling-stage systems tract; Utescher et al., 2012; Schäfer \& Utescher, 2014, fig. 13) led to the formation of extensive coastal swamps and thick (up to $300 \mathrm{~m}$ ) peat accumulations that formed the present-day, up to $100 \mathrm{~m}$ thick Main Seam of the Ville Formation (Fig. 2). Peat formation was interrupted by the deposition of clastic sediments (Frimmersdorf and 


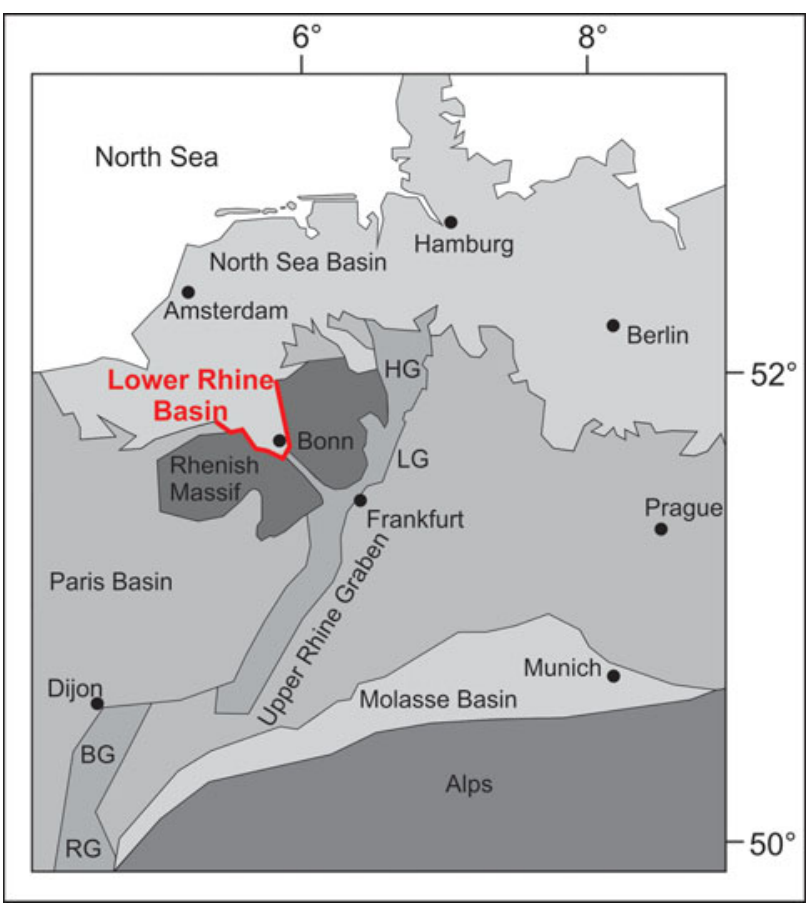

Fig. 1. A structural map of the NW European Cenozoic Rift System. The Lower Rhine Basin is located at the northern end of the Upper Rhine Graben, NW of the Rhenish Triple Junction in the area of Frankfurt (Schumacher, 2002; Sissingh, 2003; Rasser et al., 2008). BG = Bresse Graben, $H G=$ Hessen Graben, $L G=$ Leine Graben, $R G=$ Rhône Graben.

Neurath sands) as a result of repeated marine transgressions, which subdivided the Main Seam into three smaller seams (the Morken, Frimmersdorf and Garzweiler lignite seams; Fig. 2). Active exploitation of these deposits within the Lower Rhine Basin provides an excellent opportunity to examine the sedimentary succession (e.g. Petzelberger, 1994; Schäfer et al., 1996; Klett et al., 2002; Schäfer \& Utescher, 2014). The present study focuses on the Neurath Sand, a clastic unit which separates the Frimmersdorf and Garzweiler seams. The aim of the study is the three-dimensional reconstruction of the depositional setting of the Neurath Sand, integrating both detailed sedimentary profiles and mining-industry well logs.

\section{Geological framework}

The extensional Lower Rhine Basin formed in early Oligocene times (Ziegler, 1994; Klett et al., 2002; van Balen et al., 2005) as the NW extension of the European Cenozoic Rift System (Ziegler, 1992, 1994; Sissingh, 2003, 2006; Ziegler \& Dèzes, 2007; Fig. 1), with subsidence ongoing throughout the Neogene (Schäfer et al., 2005). Extension was initiated along the NW margin of the Rhenish Massif, where several NW-SE-striking faults formed, which are still active today (Ziegler, 1992; Hinzen, 2003; Sissingh, 2003, 2006; Reicherter et al., 2008; Schäfer \& Utescher, 2014; Grützner et al., 2016). These faults separate the basin into graben and horst structures (Fig. 3). Three tectonic units characterise the SE part of the Lower Rhine Basin. From E to W these are the Köln, Erft and Rur blocks, separated by the Erft and Rur faults, respectively. Towards the NW, three additional blocks occur, namely the Peel, Venlo (location of the Garzweiler open-cast mine) and Krefeld blocks. The Viersen Fault forms the contact between the latter two, while the Tegelen Fault separates the Venlo Block from the Peel Block (Fig. 3). The faults separating the individual blocks generally dip steeply $\left(70-80^{\circ}\right)$ to the SW (Schäfer et al., 2005). Subsidence across the region is variable, with up to $2000 \mathrm{~m}$ recorded for the Peel Block in the Roer Valley Graben, while the Erft Block subsidence has been measured at $1300 \mathrm{~m}$ (Klett et al., 2002).

The Peel Block, as well as the Rur Block in the German part of the basin, are structurally part of the Roer Valley Graben (Fig. 3; Houtgast \& van Balen, 2000; Michon et al., 2003), an extended rift system in the Netherlands (Geluk et al., 1994; Grützner et al., 2016). Formerly, the terms Roer Valley Graben and Lower Rhine Basin were used to refer to the same tectonic feature, and denoted either the German part (Lower Rhine Basin), or its NW extension in the Netherlands (Roer or Rur Valley Graben; Ziegler, 1992; Sissingh, 2003). Alternatively, the Roer Valley Graben has been interpreted as the central graben structure of the Lower Rhine Basin (e.g. Vanneste et al., 1999). However, in this study the terms are used sensu Geluk et al. (1994), Houtgast \& van Balen (2000) and Michon et al. (2003), and thus refer to two adjacent and structurally interlinked tectonic grabens.

As noted above, subsidence within the Lower Rhine Basin allowed the Cenozoic-age North Sea to transgress the region. In the resulting shallow-marine embayment (Schäfer et al., 1996), a clastic succession of sub- to supratidal sediments was deposited during Oligocene times (Fig. 2). Sea-level highstand in the late early and middle Miocene, coupled with warm temperate climatic conditions (Zagwijn \& Hager, 1987; Mosbrugger et al., 2005; Utescher et al., 2009), facilitated the development of extensive coastal swamps with associated peat bogs, marshes and bush forests (Mosbrugger et al., 1994). Ongoing basin subsidence, combined with compaction of the peats, resulted in the formation of thick (up to $100 \mathrm{~m}$ ) lignite accumulations (i.e. Main Seam) in the SE Lower Rhine Basin (Hager, 1986; Schäfer et al., 2005). To the NW, the Main Seam is separated into three subordinate seams: the Morken, Frimmersdorf and Garzweiler seams (=Ville Formation of Early to Mid-Miocene age). These are separated from one another by the marine sediments of the Frimmersdorf and Neurath sands, respectively. These sands were deposited as a result of short-lived marine transgressions during the Miocene which resulted in the deposition of thick (up to $100 \mathrm{~m}$ ) marine beds along the NW rim of the Miocene-age coastal mires. Following regression of the North Sea in late Miocene to Pliocene times, meandering and, subsequently, braided river systems developed on top of the marine and paralic sediments (Klett et al., 2002; Schäfer \& Utescher, 2014). 




\section{Regional distribution of the Neurath Sand in the Lower Rhine Basin}

The Neurath Sand is one of two shallow-marine sand bodies within the NW part of the Lower Rhine Basin (the other is the Frimmersdorf Sand), which separate the Main Seam into three subordinate seams (Fig. 4). Based on a sequence stratigraphical model, deposition of the Neurath Sand was continuous from 13.8 to $12.7 \mathrm{Ma}$, i.e. over a time span of $1.1 \mathrm{Ma}$ (Fig. 2; ages after Haq et al., 1987, 1988; Berggren et al., 1995; Hardenbol et al., 1998).

Two cross sections (NW-SE- and W-E-oriented; Fig. 4) across the Lower Rhine Basin, and integrated with comprehensive well 


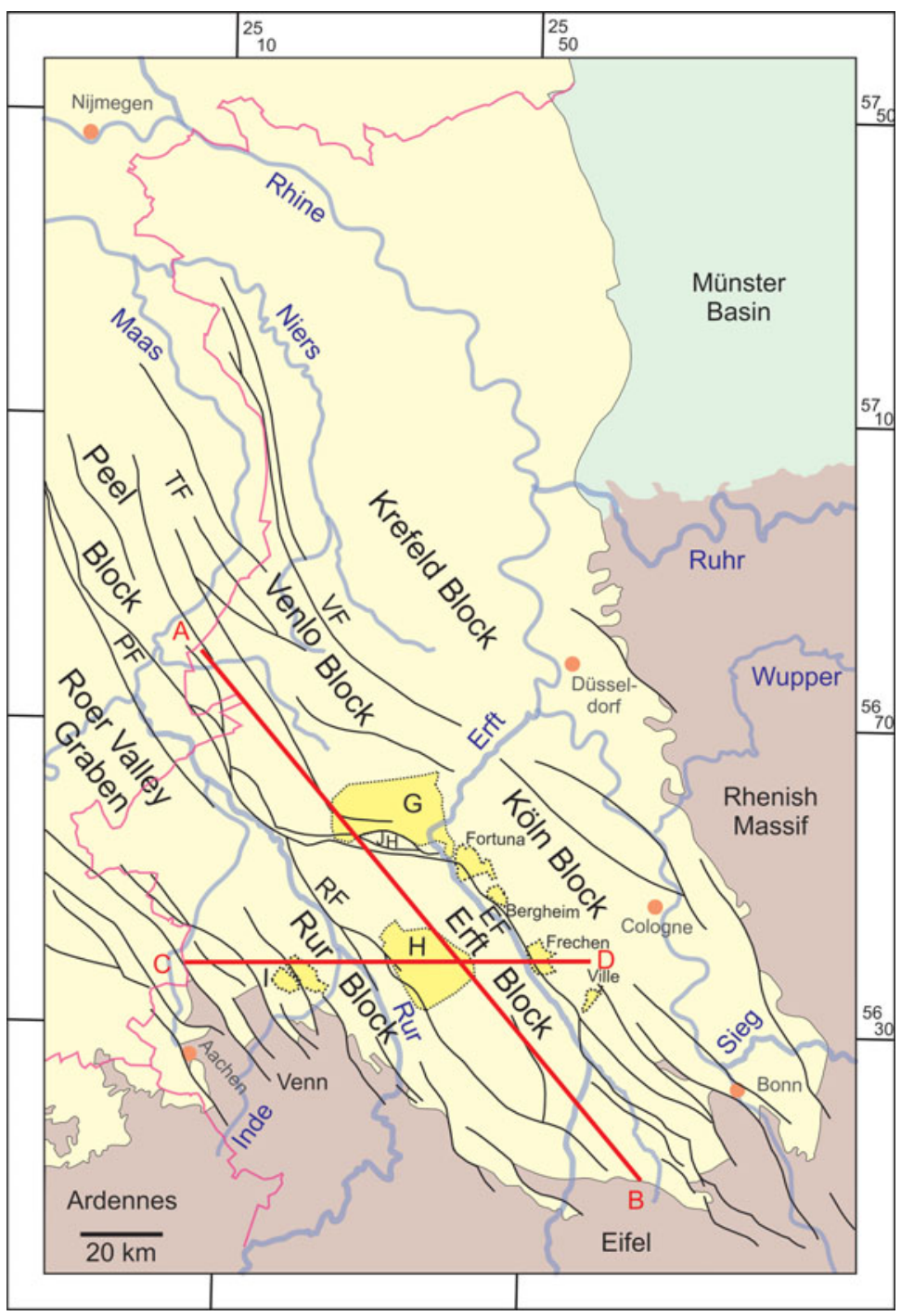

Fig. 3. A structural map of the Lower Rhine Basin. The six main tectonic blocks (Rur, Erft and Köln blocks in the SE; Peel, Venlo and Krefeld blocks in the NW) are bounded by the Rur (RF), Erft (EF), Peel Boundary (PF), Tegelen (TF) and Viersen faults (VF), as well as the fault system bounding the Jackerath Horst (JH). The Rur Block extends into the Roer Valley Graben in the NW. G = Garzweiler open-cast mine; $H=$ Hambach open-cast mine; $I=$ Inden opencast mine; pink line: Germany-Netherlands-Belgium border. The two red lines mark the position of two cross sections ( $A-B$ and $(-D)$, which are shown in Figure 4. Modified after Geluk et al. (1994), Schäfer et al. (1996), Klett et al. (2002) and Schäfer \& Utescher (2014). log data (Schäfer \& Utescher, 2014), allow the Neurath Sand to be traced laterally across the basin, while also allowing its thickness variability to be determined. It would appear that the morphology of the Neurath Sand is that of an oval lens oriented NW-SE. The maximum thickness of the Neurath Sand is up to $100 \mathrm{~m}$ on the Venlo and Erft blocks (Fig. 4). Landward (i.e. towards the SE, and the margin of the Rhenish Massif in the W; Fig. 4), the Neurath Sand thins out. This thinning is accompanied by a change in lithology (from sand to muddy sand, and eventually mud; Boersma, 1991). The maximum SE extent of the sand-rich deposits is exposed in the Hambach opencast mine (Fig. 5). Towards the region occupied by the coeval open sea (i.e. to the NW), the thickness of the Neurath Sand increases to c. $200 \mathrm{~m}$, and it interdigitates with the shallowmarine Breda Formation (Burdigalian to Mid-Tortonian age), an up to $700 \mathrm{~m}$ thick unit covering most of the Netherlands (Wong et al., 2001; Verbeek et al., 2002; Munsterman \& Brinkhuis, 2004).

\section{Methods}

In the Garzweiler open-cast mine (located at the NW end of the mining region extending along the $\mathrm{W}$ margin of the Köln Block, i.e. the Ville Ridge, and including the older Ville, Frechen, Bergheim and Fortuna mines; Fig. 3), mining activity provided access to a vertical section prepared for this study by RWE Power AG. Three freshly cut field sections along the western exploitation ramp were measured. Profile 1, with a total length of $67 \mathrm{~m}$, covered the entire Neurath Sand, from the underlying Frimmersdorf Seam through to the overlying Garzweiler Seam. Parallel profiles, located $200 \mathrm{~m}$ from each other along a N-S axis, were measured along the active exploitation ramp. Neither profile $2(35 \mathrm{~m})$ nor profile $3(24 \mathrm{~m})$ extended to the base of the Neurath Sand, due to the working level of the lignite in this part of the open-cast mine. The three profiles allowed a threedimensional facies analysis of the Neurath Sand to be carried out, as well as detailed examination of the sediments (e.g. grain 


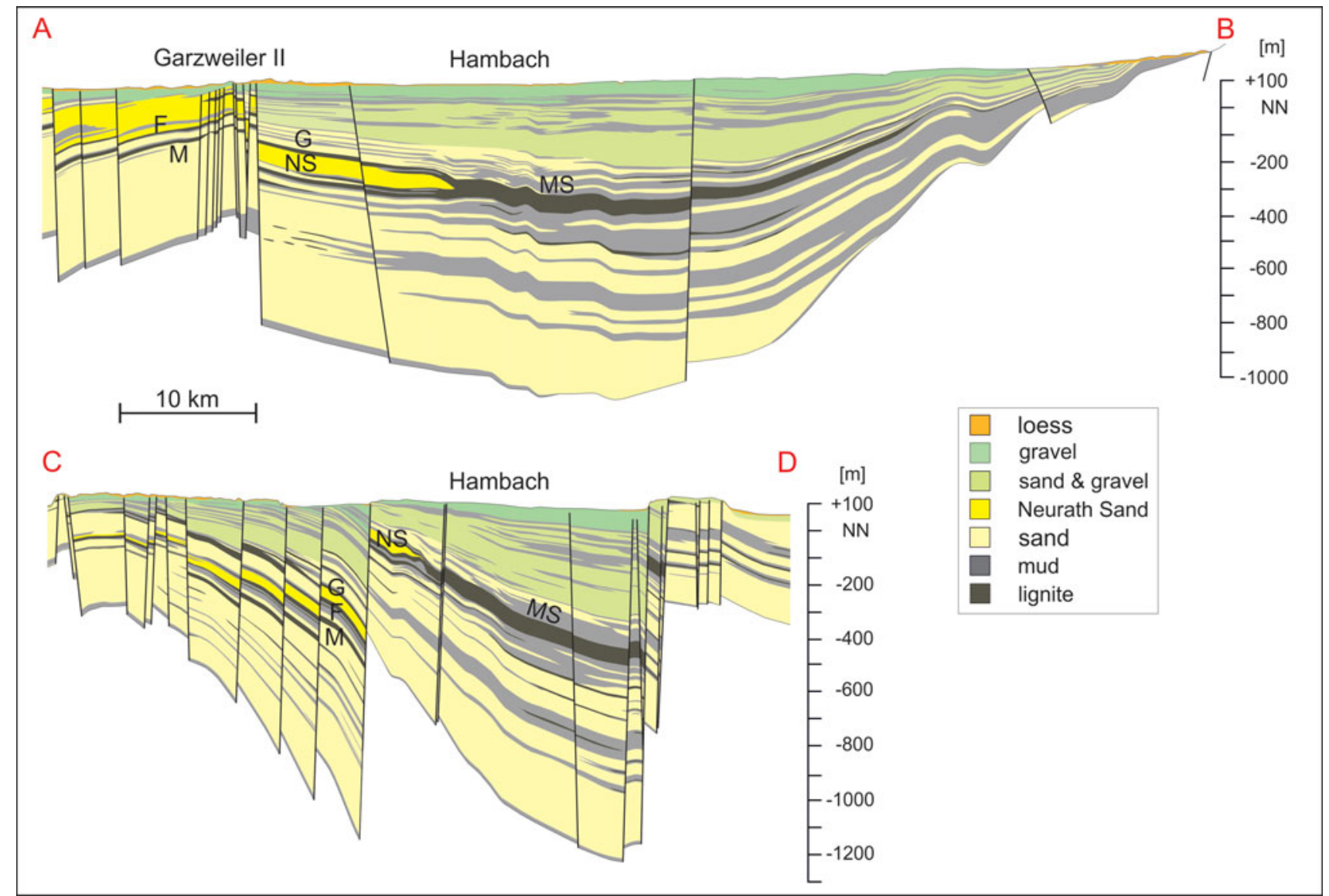

Fig. 4. Cross sections $A-B$ (NW-SE) and C-D (W-E; positions in the Lower Rhine Basin marked in Fig. 3). The Main Seam (MS) of the Middle Miocene-age Ville Formation is separated by transgressive sand units into three subordinate units: the Morken (M), Frimmersdorf (F) and Garzweiler seams (G). The Neurath Sand (NS) terminates to the SE and W, and increases in thickness to the NW. Modified after Becker \& Asmus (2005).

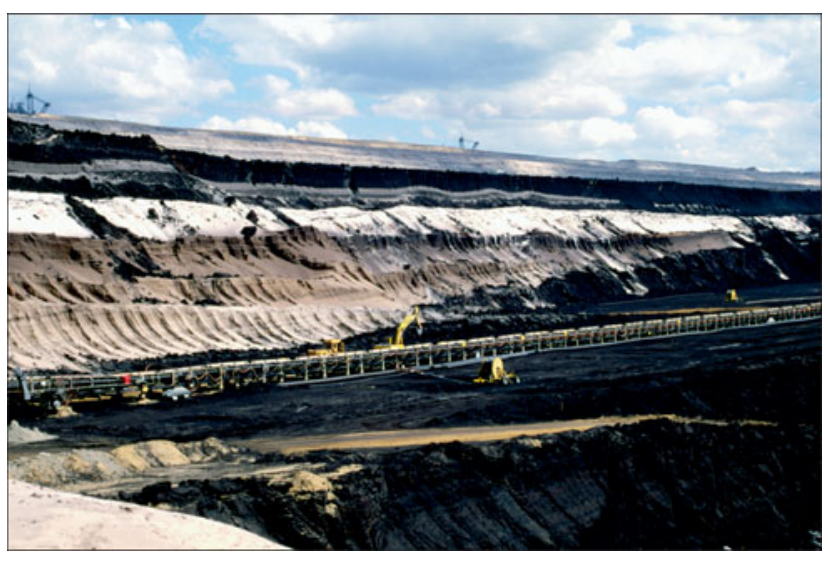

Fig. 5. The maximum extent of the Neurath Sand as exposed in the Hambach open-cast mine (1998).

size, sorting, sedimentary structures), and the integration of ichnological data. Lignite-derived humic acids have led to the dissolution of calcareous tests and shells within the sands, so the only fossils present within the Neurath Sand are ichnofossils and wood/lignite fragments. Laboratory investigations (e.g. grain-size analysis) were used to support the field observations and to provide additional information (e.g. petrological analysis). This latter analysis focused on the examination of darkcoloured sand clasts, which had been observed in all three measured profiles. These were sampled (profile 2 (6.0-6.5 m); see below) and hardened with epoxy resin, with subsequent thin sections $(n=10)$ being used to determine lithic fragment frequency and composition.

\section{Sedimentary facies and facies analysis}

Six sediment facies have been recognised in the Neurath Sand and the overlying Garzweiler Seam, ranging from muddy and coarse- to fine-grained sands through to lignite (Table 1). These are described in detail below.

\section{Muddy sands with chert-pebble lag (Smu)}

Description Dark grey-coloured, fine- to medium-grained sands with up to $15 \%$ mud which contain clasts of mud, wood and lignite (up to $2 \mathrm{~cm}$ ), concentrated near the bed base. The base of the facies is characterised by a chert-pebble layer (ranging 
Table 1. Sedimentary facies of the Neurath Sand and the overlying Garzweiler Seam, Garzweiler open-cast mine.

\begin{tabular}{|c|c|c|}
\hline Abbreviation & & Sedimentary facies \\
\hline Smu (muddy sands) & & Muddy sands with chert-pebble lag \\
\hline \multirow[t]{3}{*}{ Sf (fine-grained sands) } & Sf-u & Non-stratified \\
\hline & Sf-p & Planar-laminated \\
\hline & Sf-c & Cross- / trough cross-laminated \\
\hline \multirow[t]{3}{*}{ Sfm (fine- to medium-grained sands) } & Sfm-u & Non-stratified \\
\hline & Sfm-p & Planar-laminated \\
\hline & Sfm-c & Cross- / trough cross-laminated \\
\hline \multirow[t]{2}{*}{ Sm (medium-grained sands) } & Sm-p & Planar-laminated \\
\hline & Sm-c & Cross- / trough cross-laminated \\
\hline Sc (coarse- to medium-grained sands) & Sc-c & Cross- / trough cross-laminated \\
\hline $\mathrm{L}$ & & Lignite \\
\hline
\end{tabular}

in thickness from a single pebble to $0.75 \mathrm{~m}$; Fig. 6a) which lacks grading or structure. The matrix of the chert-pebble layer is white to light grey in colour, changing upsection into the more characteristic darker-coloured sands. Bed thicknesses range from 0.5 to $2 \mathrm{~m}$. The beds are internally non-stratified and are not graded. The ichnofossils include simple vertical and unbranched burrows of Skolithos linearis (up to $20 \mathrm{~cm}$ long; Seilacher, 1964; Alert, 1974; Hiscott et al., 1984; Howard \& Frey, 1984; MacEachern et al., 2012) and subvertical unbranched burrows with spreiten (Teichichnus ichnosp.; Fig. 6b; cf.Crimes, 1977), as well as unbranched, (sub)horizontal Planolites ichnosp (cf.Curran \& Frey, 1977). The ichnofossils are distributed throughout the beds.

Interpretation The relatively fine grain size and the presence of up to $15 \%$ of mud would suggest deposition within a relatively low- to moderate-energy environment. The chert-pebble bed at the base of this facies (Fig. 6a), however, indicates an initial high-energy transport regime, and represents a lag deposit. The lack of any internal structure within the muddy sands may result from (a) rapid and turbulent flows, (b) bioturbation or (c) remobilisation of sediments due to liquefaction. While the facies is bioturbated, the bioturbation is discrete and the facies does not have the mottled appearance associated with high degrees of bioturbation (e.g. Taylor \& Goldring, 1993; Bromley, 1996; Tonkin et al., 2010). Additionally, there is no evidence of liquefaction (e.g. dish or pillar structures). Another possibility is that the lamination is present but not visible as a result of the preparation of the section by the bucket wheels of the frontwheel loaders cutting the access ramps.

Skolithos linearis is generally found in lower intertidal to shallow subtidal settings (above fairweather wave-base) with moderate- to high-energy conditions (MacEachern et al., 2012). However, Skolithos ichnosp. has also been observed in deeper environments, e.g. the transition zone on the shelf (Desjardins et al., 2010) or deep-sea sand fans (Crimes, 1977; Uchman \& Demircan, 1999). The occurrence of Teichichnus ichnosp. (Fig. 6b) is restricted to muddy substrates in low-energy environments, which are permanently water-covered (i.e. below low-tide line; Seilacher, 1964; Pemberton \& Frey, 1984; Frey, 1990; MacEachern et al., 2012). Planolites ichnosp. is a facies-crossing ichnospecies and so does not provide any information as to specific water depths or energy milieus.

\section{Fine-grained sands (Sf)}

Description Fine-grained sands ( $<10 \%$ of mud, $<3 \%$ of mediumand coarse-grained sand) which are non-stratified (Sf-u), planar (Sf-p), cross- or trough cross-laminated (Sf-c). Within the latter two, fine-grained sands comprising very thin (1-2 mm) sand-mud laminae were observed. Non-stratified sands may contain glauconite. Along the bases of some of the individual cross-laminae, thin lags (generally one to two grains thick, and medium- to coarse-grained sand) may occur. Bed thicknesses range from 0.2 to $4.0 \mathrm{~m}$ for Sf-p down to 0.2 to $3.5 \mathrm{~m}$ for Sf-c and 0.5 to $1.0 \mathrm{~m}$ for Sf-u. Root horizons, where present, are restricted to the top of individual beds (Fig. 6c). Non-stratified and planar-laminated fine-grained sands are sporadically black and frequently comprise wood fragments.

Frequently observed Ophiomorpha ichnosp. (restricted to profile 1; Fig. $6 \mathrm{~d}$ ) are predominant within the non-stratified sands (Sf-u), but were also noted from one of the trough crosslaminated sand beds (Sf-c). The fine-grained sand beds can contain clasts of mud (up to $20 \mathrm{~cm}$ ), lignite or wood (up to $30 \mathrm{~cm}$, but generally smaller) that are either concentrated near the bed bases or distributed throughout the bed.

Within this facies (but also within other facies; see below) are beds, $20-50 \mathrm{~cm}$ thick, of black fine-grained sand which are overlain by thin beds $(20-30 \mathrm{~cm})$ comprising fine-grained, black sand clasts. The sand-clast beds (Fig. 6e) are covered by trough cross-laminated beds (up to $20 \mathrm{~cm}$ thick, containing wood fragments), topped by symmetrical ripples $(2-7 \mathrm{~cm}$ high). The black sand clasts comprise mainly monocrystalline quartz (Qm, 47.51\%; Fig. 6f; Table 2), showing undulose extinction and 



Fig. 6. Facies characteristics of the Neurath Sand. (A) Chert-pebble bed at the base of the muddy sand (Smu) lithofacies; (B) Teichichnus ichnosp. in the muddy sand (Smu) lithofacies; (C) root horizons extending down into the Neurath Sand from the overlying Garzweiler Seam; (D) Ophiomorpha ichnosp. within fine-grained sands of the unstratified fine sand (Sf-u) lithofacies; (E) black sand-clast bed in profile 3 at c. 11 m; (F) microphotograph (crossed polars) of a black sand clast from profile 2 (c. $6 \mathrm{~m}$ in profile), showing mainly quartz grains, and dark, opaque humic substances occupying the interstitial pore volume.

dust rims (indicative of phases of diagenetic crystal growth). Polycrystalline quartz $(0 \mathrm{p} ; 16.69 \%)$ is also present. Both $\mathrm{Qm}$ and Qp may include mafic inclusions (often altered to kaolinite $(3.97 \%)$ or replaced by humic gel particles) either within the crystals or along their margins. K-feldspar (5.74\%) is also present, usually as microcline or perthite, while rare plagioclase $(1.96 \%$ ) also occurs. Muscovites (on average, $0.18 \%$ ), where present, have an extinction colour suggesting they were originally biotite. Lithic fragments include quartz phyllites, phyllites, quartzites $(8.91 \%)$, as well as rare mafic $(0.83 \%$, including volcanics, mostly weathered to kaolinite) and carbonate $(0.1 \%)$ clasts. Possible glauconite was also noted (1.37\%). The sand clasts can be classified as quartz-rich feldspathic litharenites (after Folk 1974; Fig. 7; Table 2), with little variation between the various profiles or within an individual profile. The intersti- tial pore volume of the sand grains is filled with dark-coloured, opaque humic substances (Fig. 6f).

Interpretation The Sf facies contains three subfacies, as well as sand-mud laminae and black sands. The fine-grained nature of the facies would suggest deposition under low-energy conditions, although the sedimentary structures (e.g. Sf-p, Sf-c) would suggest periods of higher energy. The ichnofossil-rich beds tend to coincide with the occurrence of the structureless fine-grained sands $(\mathrm{Sf}-\mathrm{u})$, suggesting that the lack of structure is related to intense bioturbation (up to BI 4-6; Tucker, 2003) rather than an absence of sedimentary structures per se.

The cross-laminated sands (Sf-c) were deposited from migrating ripples or dunes indicative of higher wave energy, as well as tidal, wave or wind-induced currents (Dabrio, 1982; Masselink \& 
Table 2. Modal analysis of the thin sections $(n=10)$ of one black sand clast (profile 2).

\begin{tabular}{|c|c|c|c|c|c|c|c|c|c|c|c|}
\hline & & \multicolumn{2}{|c|}{1} & \multicolumn{2}{|c|}{2} & \multicolumn{2}{|c|}{3} & \multicolumn{2}{|c|}{4} & \multicolumn{2}{|c|}{5} \\
\hline \multicolumn{2}{|c|}{ Minerals } & Counts & $\%$ & Counts & $\%$ & Counts & $\%$ & Counts & $\%$ & Counts & $\%$ \\
\hline Q & qtz-mono & 274 & 50.93 & 159 & 49.53 & 194 & 48.02 & 188 & 47.96 & 205 & 42.62 \\
\hline Q & qtz-poly & 78 & 14.50 & 45 & 14.02 & 55 & 13.61 & 62 & 15.82 & 80 & 16.63 \\
\hline $\mathrm{R}$ & qtzite & 43 & 7.99 & 22 & 6.85 & 25 & 6.19 & 32 & 8.16 & 47 & 9.77 \\
\hline $\mathrm{R}$ & chert & 2 & 0.37 & 3 & 0.93 & 10 & 2.48 & 2 & 0.51 & 8 & 1.66 \\
\hline $\mathrm{R}$ & sed. lithic frag. & 46 & 8.55 & 7 & 2.18 & 38 & 9.41 & 45 & 11.48 & 16 & 3.33 \\
\hline $\mathrm{F}$ & $\mathrm{fsp}$ & 8 & 1.49 & 11 & 3.43 & 3 & 0.74 & 3 & 0.77 & 22 & 4.57 \\
\hline $\mathrm{F}$ & $\mathrm{K}$ fsp & 28 & 5.20 & 6 & 1.87 & 19 & 4.70 & 6 & 1.53 & 26 & 5.41 \\
\hline $\mathrm{F}$ & plag & 4 & 0.74 & 4 & 1.25 & 2 & 0.50 & 5 & 1.28 & 14 & 2.91 \\
\hline $\mathrm{F}$ & $\mathrm{qtz} / \mathrm{fsp}$ & 36 & 6.69 & 34 & 10.59 & 23 & 5.69 & 22 & 5.61 & 29 & 6.03 \\
\hline $\mathrm{R}$ & muscv. & 0 & 0.00 & 0 & 0.00 & 0 & 0.00 & 1 & 0.26 & 1 & 0.21 \\
\hline $\mathrm{R}$ & biotite & 1 & 0.19 & 2 & 0.62 & 4 & 0.99 & 0 & 0.00 & 3 & 0.62 \\
\hline $\mathrm{R}$ & heavy min. & 0 & 0.00 & 0 & 0.00 & 1 & 0.25 & 0 & 0.00 & 0 & 0.00 \\
\hline $\mathrm{R}$ & glauconite & 1 & 0.19 & 8 & 2.49 & 4 & 0.99 & 0 & 0.00 & 6 & 1.25 \\
\hline $\mathrm{R}$ & kaolinite & 6 & 1.12 & 19 & 5.92 & 22 & 5.45 & 16 & 4.08 & 19 & 3.95 \\
\hline $\mathrm{R}$ & phyllite frag. & 10 & 1.86 & 0 & 0.00 & 4 & 0.99 & 2 & 0.51 & 4 & 0.83 \\
\hline $\mathrm{R}$ & mafic frag. & 1 & 0.19 & 0 & 0.00 & 0 & 0.00 & 0 & 0.00 & 1 & 0.21 \\
\hline $\mathrm{R}$ & volcanic frag. & 0 & 0.00 & 1 & 0.31 & 0 & 0.00 & 6 & 1.53 & 0 & 0.00 \\
\hline \multirow[t]{3}{*}{$\mathrm{R}$} & carbonate & 0 & 0.00 & 0 & 0.00 & 0 & 0.00 & 2 & 0.51 & 0 & 0.00 \\
\hline & Total & 538 & 100.00 & 321 & 100.00 & 404 & 100.00 & 392 & 100.00 & 481 & 100.00 \\
\hline & & \multicolumn{2}{|c|}{6} & \multicolumn{2}{|c|}{7} & \multicolumn{2}{|c|}{8} & \multicolumn{2}{|c|}{9} & \multicolumn{2}{|c|}{10} \\
\hline \multicolumn{2}{|c|}{ Minerals } & Counts & $\%$ & Counts & $\%$ & Counts & $\%$ & Counts & $\%$ & Counts & $\%$ \\
\hline Q & qtz-mono & 224 & 49.67 & 185 & 52.11 & 115 & 45.45 & 185 & 48.68 & 140 & 39.33 \\
\hline Q & qtz-poly & 61 & 13.53 & 45 & 12.68 & 51 & 20.16 & 88 & 23.16 & 63 & 17.70 \\
\hline $\mathrm{R}$ & qtzite & 36 & 7.98 & 43 & 12.11 & 14 & 5.53 & 8 & 2.11 & 30 & 8.43 \\
\hline $\mathrm{R}$ & chert & 9 & 2.00 & 1 & 0.28 & 4 & 1.58 & 0 & 0.00 & 4 & 1.12 \\
\hline $\mathrm{R}$ & sed. lithic frag. & 32 & 7.10 & 19 & 5.35 & 17 & 6.72 & 20 & 5.26 & 30 & 8.43 \\
\hline $\mathrm{F}$ & fsp & 5 & 1.11 & 1 & 0.28 & 2 & 0.79 & 0 & 0.00 & 10 & 2.81 \\
\hline $\mathrm{F}$ & $\mathrm{K}$ fsp & 17 & 3.77 & 15 & 4.23 & 5 & 1.98 & 17 & 4.47 & 17 & 4.78 \\
\hline $\mathrm{F}$ & plag & 8 & 1.77 & 4 & 1.13 & 11 & 4.35 & 9 & 2.37 & 7 & 1.97 \\
\hline $\mathrm{F}$ & $\mathrm{qtz} / \mathrm{fsp}$ & 28 & 6.21 & 15 & 4.23 & 12 & 4.74 & 21 & 5.53 & 26 & 7.30 \\
\hline $\mathrm{R}$ & muscv. & 0 & 0.00 & 2 & 0.56 & 0 & 0.00 & 0 & 0.00 & 1 & 0.28 \\
\hline $\mathrm{R}$ & biotite & 4 & 0.89 & 0 & 0.00 & 1 & 0.40 & 4 & 1.05 & 3 & 0.84 \\
\hline $\mathrm{R}$ & heavy min. & 0 & 0.00 & 0 & 0.00 & 0 & 0.00 & 2 & 0.53 & 0 & 0.00 \\
\hline $\mathrm{R}$ & glauconite & 2 & 0.44 & 11 & 3.10 & 1 & 0.40 & 2 & 0.53 & 6 & 1.69 \\
\hline $\mathrm{R}$ & kaolinite & 18 & 3.99 & 10 & 2.82 & 15 & 5.93 & 15 & 3.95 & 17 & 4.78 \\
\hline $\mathrm{R}$ & phyllite frag. & 4 & 0.89 & 1 & 0.28 & 0 & 0.00 & 0 & 0.00 & 1 & 0.28 \\
\hline $\mathrm{R}$ & mafic frag. & 2 & 0.44 & 3 & 0.85 & 5 & 1.98 & 8 & 2.11 & 1 & 0.28 \\
\hline $\mathrm{R}$ & volcanic frag. & 0 & 0.00 & 0 & 0.00 & 0 & 0.00 & 0 & 0.00 & 0 & 0.00 \\
\hline \multirow[t]{2}{*}{$\mathrm{R}$} & carbonate & 1 & 0.22 & 0 & 0.00 & 0 & 0.00 & 1 & 0.26 & 0 & 0.00 \\
\hline & Total & 451 & 100.00 & 355 & 100.00 & 253 & 100.00 & 380 & 100.00 & 356 & 100.00 \\
\hline
\end{tabular}

$\mathrm{Q}=$ mono- and polycrystalline quartz; $\mathrm{F}=\mathrm{K}$-feldspar, plagioclase and feldspar/quartz aggregates; $\mathrm{R}=$ lithic rock fragments including heavy minerals, micas and chert.

Anthony, 2001; Reynaud \& Dalrymple, 2012; Hunt et al., 2015). The parallel-laminated sands (Sf-p) were also deposited under low-energy conditions, most probably aeolian (0tvos, 2000; Collinson et al., 2006). However, the planar-laminated finegrained sands can also include interbedded sand-mud laminae, which have been interpreted as tidal rhythmites (Tessier et al., 1995; Reesink \& Bridge, 2007; Bungenstock \& Schäfer, 2009). Such laminae record the passage of tidal currents alternating with periods of tidal slack water (Visser, 1980; Reesink \& Bridge, 2007). The occurrence of two coupled mud laminae alternating 


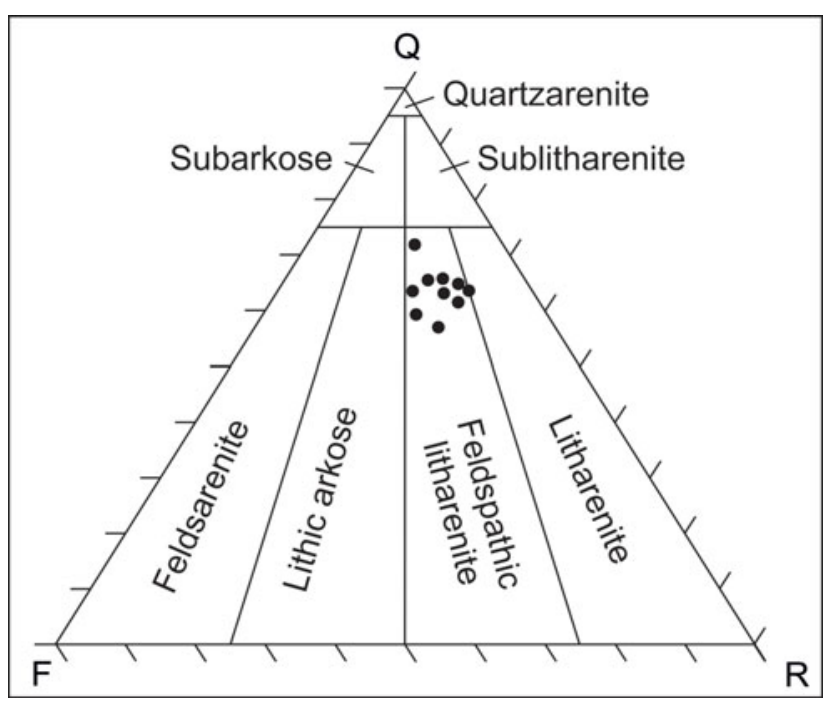

Fig. 7. Modal analysis of thin sections $(n=10)$ of one black sand clast (profile 2) (after Folk, 1974; Graham \& Midgley, 2000). These data are from the same clast as illustrated in Figure $6 e . F=$ feldspar, $Q=$ quartz, $R$ $=$ rock fragments.

with thin sand laminae could be interpreted as ebb and flood cycles, with such coupled mud laminae generally restricted to environments below low-tide level (Hovikoski et al., 2005).

The black clasts were indurated as a result of their infiltration by black humic gels most probably derived from exposed and reworked lignites as well as from nearby coastal mires. Alteration, and related induration, was initiated by the passage of low-pH humic acids, which allowed the sands to be eroded from the underlying black sand, and redeposited as lags. The humic gels are preserved as dark-brown films surrounding the sand grains, while organic substances are preserved as black angular fragments in the pore spaces (Fig. 6f).

Wood fragments indicate the input of organic material from nearby coastal mires, whereas black sands at the top of the Neurath Sand have been infiltrated by humic gels from the overlying Garzweiler lignite seam. Root horizons within the fine-grained sands would appear to migrate downwards from the overlying lignite seams. Such concentrations of root horizons would suggest the former presence of a well-vegetated horizon, and one located in a continental/near-coastal setting (Darscheid, 1981). This horizon would thus represent the period of initial colonisation by plants following the phase of marine regression. The black sand beds, frequently covering the rooted horizons, suggest an infiltration of humic gels from the overlying lignite deposits.

Ophiomorpha ichnosp. (Fig. 6b) occurs in a range of energy settings, from sand-rich, moderate- to high-energy, to muddy, low-energy marine environments. It is generally found in marine environments ranging from lower intertidal through to shoreface, and above storm wave-base (Seilacher, 1964; Hiscott et al., 1984; Howard \& Frey, 1984; MacEachern et al., 2012).

\section{Fine- to medium-grained sands (Sfm)}

Description The fine- to medium-grained sands (Sfm) comprise three subfacies, including non-stratified (Sfm-u; $0.6-1.0 \mathrm{~m}$ thick), planar (Sfm-p; 0.3-1.0 m) and cross-laminated/bedded (Sfm-c; $0.3-2.0 \mathrm{~m}$ ) sand beds. Lamination within the latter beds, in particular, results from the alternation of fine- with mediumgrained sand laminae. Within individual beds, planar-bedded, fine- to medium-grained, sand alternations have been observed. These beds may show a fining upward. Within the trough crosslaminated sand beds (Sfm-c), mud-sand laminae may occur. Clasts of mud, wood and lignite, as well as roots, are very common within both the non-stratified and the planar-laminated sands.

Interpretation Fine- to medium-grained sands indicate deposition within a moderate-energy setting, with the fine- and medium-grained sand alternations suggesting regularly changing energy levels. Within the planar bedded sands, the finingup would suggest waning energy levels. Clasts of lignite and wood within the non-stratified and planar-laminated sand possibly indicate seaward transport of organic matter from the adjacent peat/swamp environment, as well as the reworking of laterally exposed lignite deposits (e.g. peat/lignite accumulations of the present-day Frimmersdorf Seam). Rhizoturbated sediments, as described above, indicate the presence of a vegetation cover overlying the sand deposits.

Cross- and trough cross-lamination would suggest that these beds were deposited in a depositional setting controlled by wave or tidal currents. Such a setting would be supported by the presence of tidal bundles (sand-mud laminae) within the facies.

\section{Medium-grained sands (Sm)}

Description This lithofacies comprises (trough or planar) crosslaminated/bedded sand beds (Sm-c; $1.0-1.5 \mathrm{~m}$ thick), as well as planar-laminated sand beds (Sm-p; $0.5-2.5 \mathrm{~m}$ thick). Planarlaminated, medium-grained sand beds (rarely black) may show evidence of upward fining within individual beds. In addition, lamina thickness decreases within individual beds. The crosslaminated/cross-bedded sand beds may contain mud clasts (up to $2 \mathrm{~cm}$ ), as well as rare coarse-grained laminae.

Medium-grained, cross-laminated/bedded sand units also contain beds with concentrations of black sand clasts. These sand clasts are surrounded by a matrix of grey medium-grained sand, which also contains concentrations of coarse-grained sand (concentrated at the base of the clast bed), small chert pebbles (up to $0.5 \mathrm{~cm}$ in diameter and concentrated within the interstices between the black sand clasts) and wood fragments (up to $1 \mathrm{~cm}$; also concentrated within the interstices). These sandclast beds have a lateral extent of up to $4 \mathrm{~m}$.

Interpretation The medium-grained sands (Sm) were deposited in a setting characterised by moderate to high energy. 
Planar-laminated, medium-grained sands (Sm-p) are interpreted as high-energy laminites, which are characteristic of the swash zone. The presence of cross-laminated, medium-grained sands (Sm-c) would suggest deposition in an environment influenced by wave and tidal activity (de Raaf \& Boersma, 1971; Hori et al., 2001; Yang et al., 2005) as well as the migration of large-scale dunes (Reynaud \& Dalrymple, 2012), thus suggesting deposition within a ridge-and-runnel system (Dabrio, 1982; Masselink \& Anthony, 2001). Such systems form as a result of the high wave energy within the breaker zone (dissipative shoreline; e.g. Stive et al., 2002; Aagaard \& Hughes, 2006). The ridges comprise trough cross-laminated dunes which are oriented parallel to the coastline. However, due to wave activity, tidal currents or the influence of an estuarine system, dunes may also be orientated perpendicular to the shoreline (Dalrymple et al., 2012). On top of these dunes, wave activity can lead to the deposition of high-energy parallel, or planar cross-lamination (Schäfer, 2010). Horizontal surfaces between individual trough cross-laminated sections formed as a result of the erosion of the upper part of dunes, followed by the build-up of new sand dunes on top (i.e. compound dunes; Reynaud \& Dalrymple, 2012). Mud clasts were probably eroded from adjacent muddy tidal flats (Fan, 2012), and these were subsequently deposited on the lee sides of the sand dunes/ridges/mega-ripples. The coarser-grained laminae within the Sm-c are probably indicative of periods of increased wave or tidal energy.

Sand dunes in such ridge-and-runnel systems are often cut by offshore-directed rip currents (Aagaard et al., 1997). The characteristic, laterally restricted black sand-clast beds with erosive lower boundaries may have been the result of these highvelocity currents, which erode small channels into the trough cross-laminated ridges and dunes (Dabrio, 1982; Masselink \& Anthony, 2001; Hughes, 2012). Within the sand-clast beds, coarse-grained sands and chert pebbles embedded into the matrix of medium-grained sands are indicative of periods of highervelocity currents. The sand clast beds are covered by small-scale ripple marks, indicating a decrease in current velocity.

Rip currents, such as those presumed responsible for the generation of the black sand-clast beds, have been regarded as an important pathway for the exchange of water and sediment between the surf zone and the inner shelf environments (Aagaard et al., 1997; Haller, 2002; Castelle \& Coco, 2012). The velocities within rip currents increase during ebb tides (Aagaard et al., 1997) and therefore may have been responsible for the seawarddirected transport of wood fragments, peat or lignite clasts, as well as chert pebbles.

\section{Coarse- to medium-grained sands (Sc)}

Description Coarse- to medium-grained sand beds, which range in thickness from 0.3 to $2 \mathrm{~m}$, are exclusively crosslaminated/bedded (Sc-c), and may be graded (fining up). They contain evidence of both planar cross- and trough cross- lamination/bedding, although the former is more common. Individual cross-laminae within this section may contain finegrained, organic-material-rich and black sands. The crosslaminated beds are internally bounded by horizontal surfaces, separating the individual sets of cross-lamination and bedding. Wood fragments (branches and roots, up to $1 \mathrm{~cm}$ in diameter), where present, have been deposited parallel to these horizontal, erosive surfaces, as well as parallel to the trough cross-laminae. Clasts also present within this facies include mud and lignite fragments. Up to $2 \mathrm{~cm}$ thick mud beds, covering the trough cross-laminated, coarse- to medium- grained sand beds were also present.

Interpretation This lithofacies was probably deposited in a higher-energy environment in a shallow-marine setting, influenced by waves and tidal currents (de Raaf \& Boersma, 1971; Hori et al., 2001; Yang et al., 2005; Reynaud \& Dalrymple, 2012). The planar cross- and trough cross-laminated/bedded beds are indicative of large migrating compound dunes (Collinson et al., 2006; Reynaud \& Dalrymple, 2012), and therefore may also be related to the development of a ridge-and-runnel system (see above). The lignite and wood fragments were most probably derived from the erosion of adjacent coastal mires.

\section{Lignite (L)}

Description The lignite lithofacies comprises thick (up to $10 \mathrm{~m}$ ) lignite beds. The beds may contain large wood fragments (branches, tree trunks, up to $4 \mathrm{~m}$ in length and $1 \mathrm{~m}$ in diameter), which were deposited parallel to the bedding direction (i.e. possibly not in situ), as well as (sub)vertically oriented wood remains (probably in situ). Root horizons, extending downward from the lignites into the underlying sands, are common.

Interpretation The lignite deposits form part of the Garzweiler Seam, the uppermost of the three seams of the Ville Formation (Hager, 1993; Schäfer et al., 2004; Schäfer \& Utescher, 2014). They were deposited within a coastal mire adjacent to the Serravallian-age North Sea. The mire comprised areas of different floral assemblages, based on their position and distance to the coastline, as well as water availability.

\section{Facies associations in sediment profiles}

Three profiles, ranging in thickness from 24 to $67 \mathrm{~m}$, were measured from the Neurath Sand and overlying Garzweiler Seam in the Garzweiler open-cast mine and provide either a complete (profile 1) or partial (profiles 2 and 3) section through the sand body. The profiles can be subdivided, on the basis of the sedimentary facies present, into six facies associations (FA; Fig. 8), and are described below. 


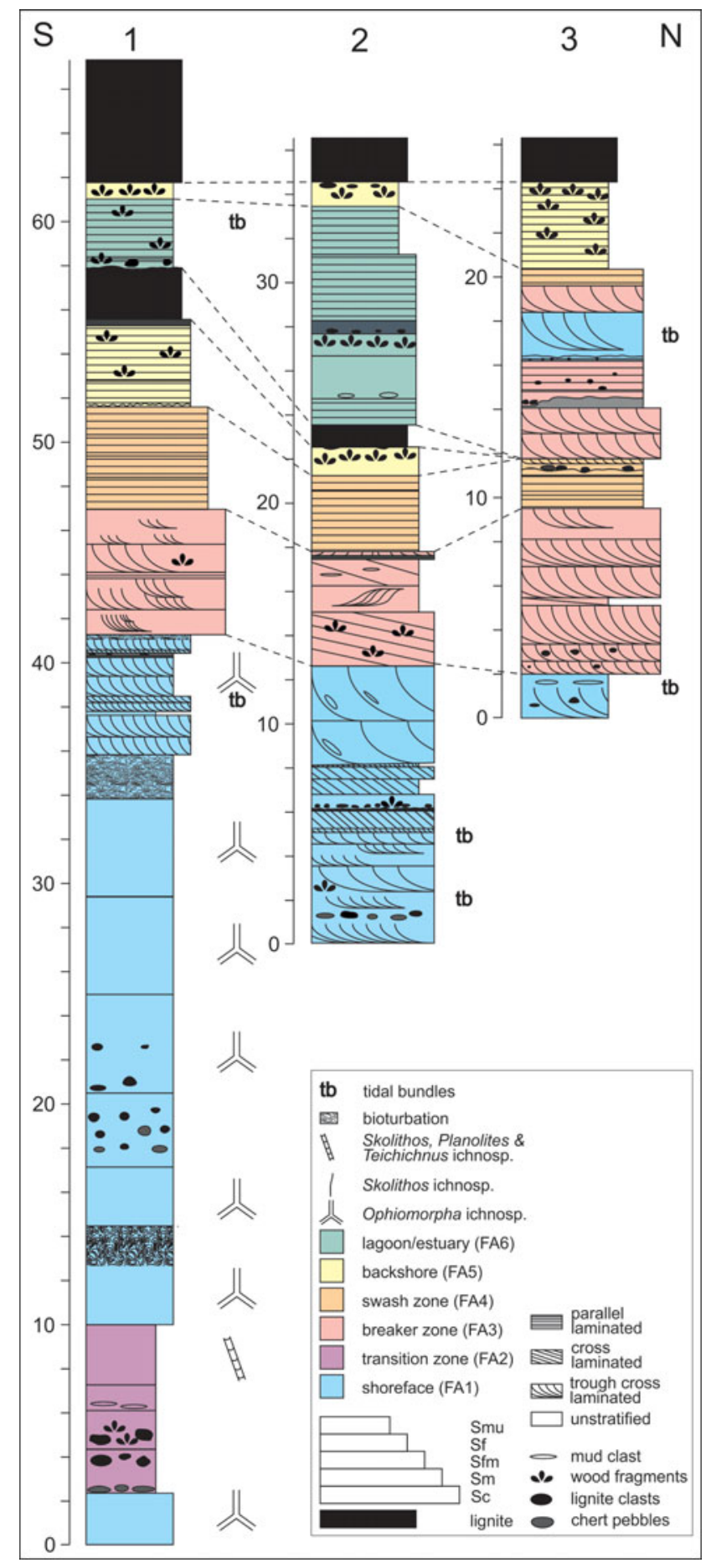

Fig. 8. The measured profile through the Neurath Sand, Garzweiler opencast mine. The three sections 1,2 and 3 are laterally positioned $200 \mathrm{~m}$ from one other along a $\mathrm{N}-\mathrm{S}$ axis. Six facies associations (FA1-6) have been identified, composed of the various sedimentary facies (six in total), including lignite, medium- to coarse-grained sand, medium-grained sand, fine- to medium-grained sand, fine-grained sand and muddy sand.

\section{Facies association 1}

The lowermost facies (FA1) of the Neurath Sand is subdivided into three parts (FA1a, b, c) and comprises three facies (Sf-u, Sf-c, Sfm-c). The lowermost parts (FA1a, b) are only present in profile 1, which commences with $2.4 \mathrm{~m}$ (FA1a) of heavily bioturbated sands (Sf-u) containing Ophiomorpha ichnosp. The horizontal Ophiomorpha ichnosp. burrows are mainly oval in shape, presumably as a result of subsequent compaction. Following an $8 \mathrm{~m}$ interval of FA2 (see below), the second part (FA1b) commences. This comprises mainly bioturbated sands (Sf-u), but also includes cross-laminated sand (Sf-c) (Fig. 8). Within the former, the percentage of bioturbation increases markedly from base to top within the individual beds. Bed tops are sharp (erosion); bioturbation recommences in the overlying bed.

The uppermost part of the facies association (FA1C) can be traced across all three sedimentary profiles (Fig. 8). This part comprises cross-laminated sands (Sf-c) and fine- to mediumgrained sands (Sfm-c), both of which also include tidal bundles, with a black sand/sand-clast layer also present in profiles 1 and 2.

Interpretation As noted above, FA1 can be subdivided into three parts. The lowermost two parts (FA1a, b) are broadly similar (both comprising mainly Sf-u), while FA1c comprises mainly Sf-c and Sfm-c. FA1a, b would appear to have been deposited in a low-energy marine environment on the basis of grain size, and the presence of abundant Ophiomorpha ichnosp (Seilacher, 1964; Hiscott et al., 1984; Howard \& Frey, 1984; MacEachern et al., 2012).

The uppermost part (FA1C) comprises mainly fine- (occasionally medium-)grained sands with well-developed planar and trough cross-lamination (Sf-c, Sfm-c), as well as tidal bundles and black sand/sand-clast beds (Fig. 6e). The former suggest deposition in a higher-energy setting than FA1a, b, thus evidencing a gradual increase in environmental energy within the lower part of the Neurath Sand. Deposition was most probably within the upper shoreface part of a subtidal environment, in contrast to the lower shoreface setting for FA1a, b. It is also possible that the transition from FA1a, $\mathrm{b}$ to FA1c marks a time gap between the two phases of this facies association. However, if that were the case, then it might be expected that a marked erosional horizon would be present at the boundary between FA1b and FA1c in profile 1, or even possibly a lag deposit. In the marked absence of both, it would appear more feasible to conclude that the transition represents a phase of shallowing within the broader depositional setting. The presence of tidal bundles (occasionally including both flood and ebb couplets; Hovikoski et al., 2005; Schäfer, 2010) in FA1c would confirm the subtidal setting. Trough cross-lamination may be indicative of wave activity; thus, FA1c was probably deposited within a ridge-and-runnel system below the low-tide line. Lignite and mud clasts are also present with the latter, most probably 
derived from the reworking of adjacent tidal flats (indicated by mud deposits bounding the Neurath Sands in the S; Schäfer \& Utescher, 2014), while the large wood fragments (e.g. up to $30 \mathrm{~cm}$ long branches) were probably transported by fluvial and tidal currents from the coastal mires. Similarly, the presence of organic fragments within the black sand/sand-clast layers would suggest proximity to abundant organic sources.

\section{Facies association 2}

Facies association 2 (FA2), which is only present in profile 1 , comprises just one facies (Smu) in five different beds. It commences with a chert-pebble lag where the matrix is lightcoloured. This passes upsection into a darker-coloured sand, with no evidence of any grading. The darker sands contain clasts of wood and lignite (mud clasts are present at the base of one bed at c. $6 \mathrm{~m}$ ) concentrated in the lowermost beds of FA2 (Fig. 8). The overlying beds contain ichnofossil assemblages with initially a concentration of Skolithos linearis in the middle part of FA2, with Planolites ichnosp., Teichichnus ichnosp. and Skolithos linearis concentrated near the top of FA2 at c. $9 \mathrm{~m}$ (Fig. 8).

Interpretation The chert-pebble lag indicates an initial highenergy depositional environment which changed rapidly to a lower-energy one. Chert pebbles within the Ville Formation have been interpreted as marine deposits of the shoreface environment (Petzelberger, 1994), possibly reflecting a transgressive surface (Utescher et al., 2012). The cherts are possibly derived from the Aachen-Limburg carbonate plateau (Albers \& Felder, 1981). Karstification of the Cretaceous-aged carbonates in the Aachen-Maastricht-Liège area (W margin of the Lower Rhine Basin; or possibly from the London-Brabant High?) was followed by transport of chert pebbles, commencing with the Oligoceneage transgression (Albers \& Felder, 1981). During Oligocene and Miocene times, the chert pebbles were redistributed and deposited within marine sediments in the Lower Rhine Basin (Albers \& Felder, 1981; Petzelberger, 1994).

The overlying non-stratified muddy sands (Smu) most probably represent a period of increasing water depth (following FA1), and decreasing environmental energy, which would be indicative of a transition zone. This is confirmed by the presence of Skolithos linearis, Planolites ichnosp. and Teichichnus ichnosp., which are indicative of the low- to moderate-energy conditions below storm wave-base (MacEachern et al., 2012).

\section{Facies association 3}

Description. FA3 can be observed within all three profiles, although its maximum thickness is only seen in the northernmost profile (profile $3,7.5 \mathrm{~m}$ at the base, and $6.4 \mathrm{~m}$ within the upper part of the profile, with up to $1.75 \mathrm{~m}$ of FA4 separating these two units); the thicknesses are reduced in profiles $1(5.4 \mathrm{~m})$ and $2(5.2 \mathrm{~m})$. The facies association consists of two lithofacies, comprising cross-laminated and cross-bedded, medium-grained sands (Sm-c), as well as cross-laminated/cross-bedded, coarseto medium-grained sands (Sc-c). The sands in profiles 1 and 3 are mainly trough cross-laminated/bedded (Fig. 9a), while in profile 2 they are predominantly planar cross-laminated/bedded. In contrast to FA1 no tidal bundles were observed in FA3.

Interpretation The grain-size and sedimentary structures, as well as the absence of tidal bundles and ichnofossils, would suggest that the sand beds of FA3 were deposited in a lower intertidal (foreshore) environment. This setting is characterised by wave processes, as well as the regular exposure and covering during low and high tides, respectively (Le Hir et al., 2000; Fan, 2012; Reynaud \& Dalrymple, 2012).

\section{Facies association 4}

Description Facies association 4 (FA4) comprises three facies, dominated by parallel-laminated, medium-grained sand beds $(S m-p)$, and rare fine- to medium-grained beds (Sfm-p), sometimes alternating, or fining/thinning upwards. In profile 1 , the FA is topped by a $20 \mathrm{~cm}$ bed of cross-laminated sand with ripple lamination (Sm-c).

Interpretation The medium-grained, planar-bedded sands indicate deposition within the upper foreshore (Clifton, 1981). These beds formed under a high-energy flow regime, when breaking waves cause swash and backwash flows on the beach surface (Aagaard \& Hughes, 2006; Masselink \& Puleo, 2006). Alternations of fine- to medium-grained with medium-grained sand beds, as well as fining-up beds, suggest variable energy conditions within the upper foreshore, possibly related to variations in wave height (e.g. seasonal, varying tidal current velocities). The thinning-upward pattern observed within the laminae of profile 3 may be related to changes in water depth and a possible shift of the depositional setting from the swash to the breaker zone at the top of the FA (Fig. 9b). The small-scale ripples (Sm-c) most probably were deposited at the high-tide level, and mark the transition from the high-energy foreshore setting to the overlying backshore environment (FA5; see below).

\section{Facies association 5}

Description This FA (Fig. 9c), which can be traced across all three profiles, comprises three facies: fine-grained sand (which may be non-stratified, Sf-u, as well as planar-laminated, Sf-p), fineto medium-grained, planar-laminated/bedded sand (Sfm-p) and thick (up to $10 \mathrm{~m}$ ) lignite deposits (L). In addition, the FA5 overlies both FA4 and FA6 (Fig. 8). The sands are rich in both wood fragments and lignite clasts, with the concentrations increasing towards the lignite (i.e. near the top of the FA). The boundary between the lignites and sands is characterised by extensive root horizons (Fig. $6 \mathrm{c}$ ), while the sands immediately underlying 

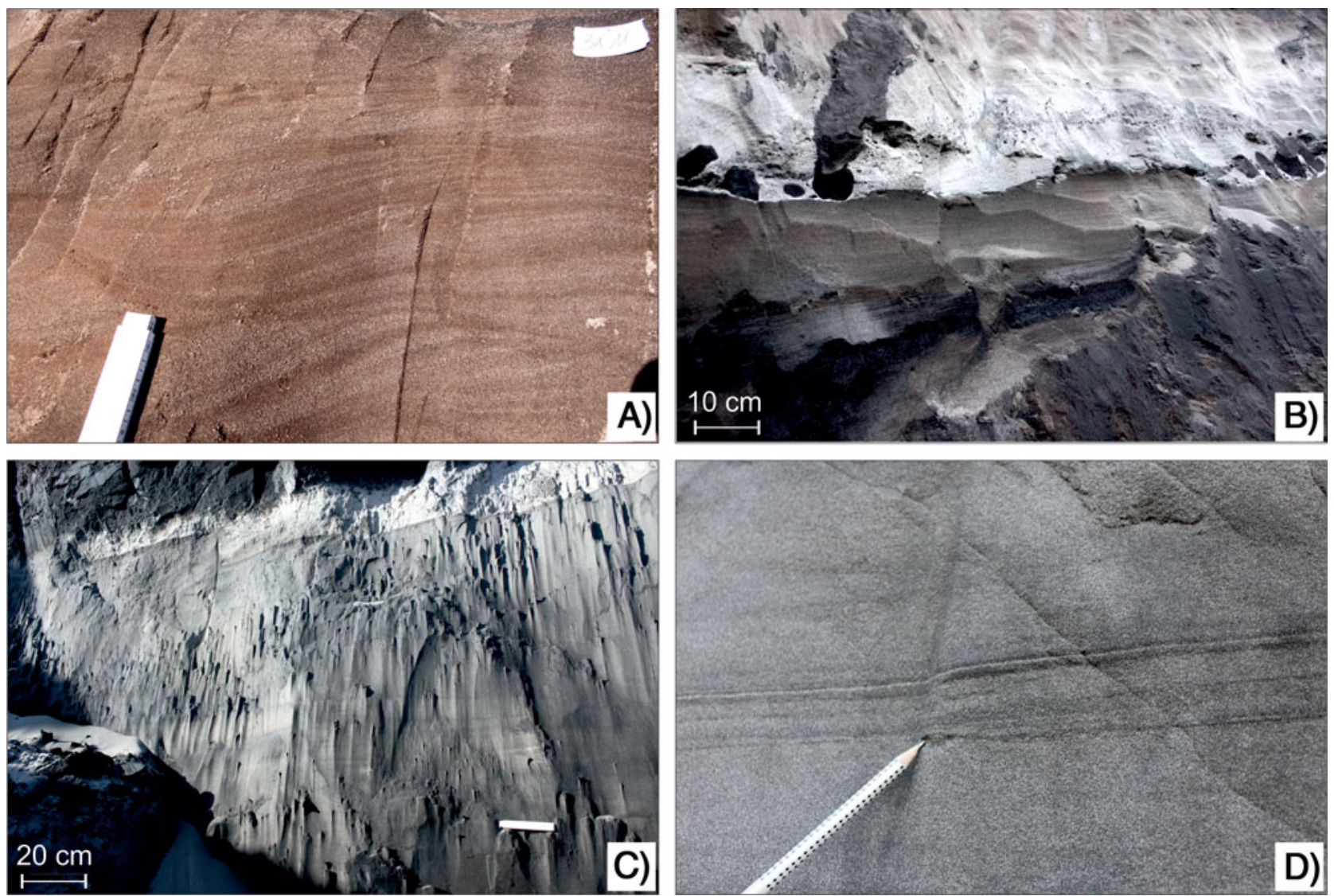

Fig. 9. Selected facies associations from the Neurath Sand. (A) Cross-laminated sands from FA3, profile 2; (B) planar-laminated, brown high-energy sands (FA4, swash zone), overlain by deposits of the breaker zone (FA3, light-grey sands). The overlying FA3 initiates with an erosionally bounded black sand-clast bed; (C) planar-laminated, fine- to medium-grained sands (comprising wood fragments) of the FA5 underlying the Garzweiler lignite seam (profile 1); (D) tidal rhythmite (sand-mud-sand-mud) in planar-laminated fine-grained sands of FA6 (profile 1).

the lignites are generally black. The boundaries between sand deposits and the overlying lignite are commonly gradational.

Interpretation The sediment grain sizes, sedimentary structures (predominance of parallel lamination as a result of aeolian deposition) and the presence of lignite would suggest that FA5 was deposited in a backshore environment with an adjacent coastal mire (Bartholdy, 2012). The sand-rich lower part of the FA provides a link between the shallow-marine foreshore sediments and the coastal peat deposits, which formed subsequent to the marine regression (Bartholdy, 2012). The black colour of the sands directly underlying the lignites resulted from infiltration of mobile dispersed organic matter (humic gels) derived from the lignites (see above).

\section{Facies association 6}

Description This FA comprises sand-rich lenses which show an irregular lateral distribution within the Garzweiler Seam, and is present in only two of the measured profiles (Fig. 8). The sand-rich lenses of FA6 comprise three lithofacies, including planar-laminated, fine-grained sands (Sf-p), and fine- to medium-grained sands, which are either non-stratified (Sfm- u), or planar-laminated (Sfm-p), with a clear erosive boundary (characterised by a concentration of wood fragments and angular to rounded lignite clasts) present in profile 1. Tidal bundles may also be present (Fig. 9d). The upper part of the FA is characterised by the presence of root horizons (extending from the overlying lignite) and rare lignite concentrations.

Interpretation The sand lenses most probably have a marine origin, based on the presence of tidal bundles (Dalrymple et al., 1992; Archer, 1996; Stupples, 2002; Mazumder \& Arima, 2005; Kvale, 2012), with deposition occurring in a moderate-energy setting. Although these deposits combine characteristics of the subtidal, intertidal and supratidal environments, it is probable that they represent deposition in a bight, lagoon or estuarine setting due to the limited lateral extent of the sand bodies.

\section{Discussion}

\section{Depositional model}

Based on our detailed facies analysis from three measured sedimentary profiles, the sediments of the Neurath Sand from the Garzweiler open-cast mine are interpreted as a 
transgressive-regressive succession. The sequence of events, which occurred in the shallow-marine North Sea in Serravallian times, resulted in the deposition of a series of units as outlined below.

The base of the succession is represented by the lignites of the Frimmersdorf Seam, originally laid down in a near-coastal swamp environment which was slowly transgressed by the North Sea. The contact between the Neurath Sand and the underlying Frimmersdorf Seam was not exposed during the profile survey of this study, although previous studies suggest it was erosional (Schäfer \& Utescher, 2014). The lowermost preserved glauconitebearing sediments (containing Ophiomorpha ichnosp.) were deposited in a shoreface environment (subtidal), i.e. within the area between low-tide level and the storm wave-base. Ophiomorpha ichnosp. are common in beach and shallow subtidal settings (Seilacher, 1964; Hiscott et al., 1984; Howard \& Frey, 1984; MacEachern et al., 2012) and can be compared to the modern shrimps Callianassa major (Frey et al., 1978). Ophiomorpha ichnosp. is frequently found in marine sediments of the Lower Rhine Basin (e.g. Ophiomorpha nodosa; Suhr, 1982, 1989; Petzelberger, 1994).

The Ophiomorpha ichnosp.-rich bed is overlain by an extensive chert-pebble bed which forms a significant marker horizon within the Garzweiler open-cast mine. Chert pebbles are widely distributed in the marine deposits of the Lower Rhine Basin (Petzelberger, 1994) and have been traced back to the Aachen-Limburg carbonate plateau (Albers \& Felder, 1981). Following intense karstification of Cretaceous-aged carbonates, the residual cherts were redistributed throughout the Lower Rhine Basin by the repeated transgressions which occurred across the region (Albers \& Felder, 1981). In the Neurath Sand, it has been suggested that the chert-pebble bed represents a transgressive surface (Utescher et al., 2012).

The overlying muddy sands (FA2) suggest a marked decrease in ambient energy levels within the depositional setting. This, together with a possible increase in water depth as suggested by the ichno-assemblage (Skolithos linearis, Planolites ichnosp. Teichichnus ichnosp.), marks a change to a transitional environment, namely a nearshore setting linking the beach and shelf environments (MacEachern et al., 2012). These transitional deposits represent the maximum flooding stage of the Lower Rhine Basin in Serravallian times, and their deposition (heralded by the deposition of the chert-pebble unit) was followed by the slow onset of regressive conditions (FA1 overlying FA2). The regressive period is represented by sands deposited within a subtidal environment. These contain Ophiomorpha ichnosp. in their lower parts, and are covered by (trough) cross-laminated sand units formed as dunes in a ridge-and-runnel system. The presence of sand-mud couplets has been interpreted as unequivocal evidence of tidal activity. These commonly occur as two paired couplets (i.e. sand-mud-sand-mud) and their presence would suggest that both ebb and flood currents were strong enough for sand transport to occur (Hori et al., 2001). These tidal bun- dles are indicative of subtidal conditions, as well as deposition within channels or estuaries (Dalrymple et al., 1992; Archer, 1996; Stupples, 2002; Mazumder \& Arima, 2005; Kvale, 2012).

The regressive trend continued with the deposition of a series of sand beds within the foreshore environment (FA3, FA4). This intertidal succession commenced with the deposition of the sediments of the breaker zone, a high-energy setting dominated by wave and tidal processes. The ridge-andrunnel system within this sedimentary environment results from wave activity, tidal processes and longshore currents (Dabrio, 1982; Kroon \& Masselink, 2002). These ridges comprise large to very large sand dunes (Reynaud \& Dalrymple, 2012) covered by smaller dunes and resulting in the formation of a complex pattern of compound cross-bedding (also observed in the Neurath Sand deposits). The overlying planar-laminated/bedded, medium-grained sands are also interpreted as intertidal deposits, although these high-energy laminites were probably deposited in the swash zone of the upper foreshore, as a result of the uprush and backwash of strong and unsteady wave flows on the beachface (Masselink \& Puleo, 2006).

The overlying supratidal sands (FA5) were deposited on the beach surface above high-tide level. Small ripple structures between the supratidal and the underlying intertidal deposits indicate the high-tide line, or beach berm, thus marking the position of maximum tidal flooding (Schäfer, 2010). There is no evidence of aeolian dune deposition within the Neurath Sand. Boersma (1991) suggested that low or non-existent dunes within the Lower Rhine Basin were the result of wet substrates at the backshore, associated with high water-levels in a back barrier lagoon. The backshore sands were, in turn, overlain by lignite, reflecting the accumulation of paralic peats in nearshore marshes and mires. The peat accumulations within the coastal mire can be up to $30 \mathrm{~m}$ thick ( $10 \mathrm{~m}$ thick present-day Garzweiler Seam) as a result of continuous subsidence of the basin. Roots from the plants growing in these paralic environments penetrated into the underlying sands (Fig. 6c) of the backshore environment. The degree of root penetration would suggest that the sands were flushed of marine interstitial pore waters and replaced with fresh water from rain and rivers. This flushing presumably occurred prior to the development of a continental flora (with the possible exception of saline-tolerant plants which represent the early pioneer plants on the recently drained surface; however, the remaining roots probably represent subsequent vegetation, based on the diameter and length of the roots; Darscheid, 1981). Various floral assemblages growing within the Miocene-aged mires have been analysed, depending on the distance to the sea as well as water availability (M. Teichmüller, 1958; R. Teichmüller, 1958).

Based on anatomical studies of wood and palynological data, the typical peat-forming vegetation of the coastal mires consisted of diverse open mixed forests and scrubs comprising conifers and angiosperms (van der Burgh, 1973; von der Brelie \& Wolf, 1981; Mosbrugger et al., 1994; Figueiral et al., 


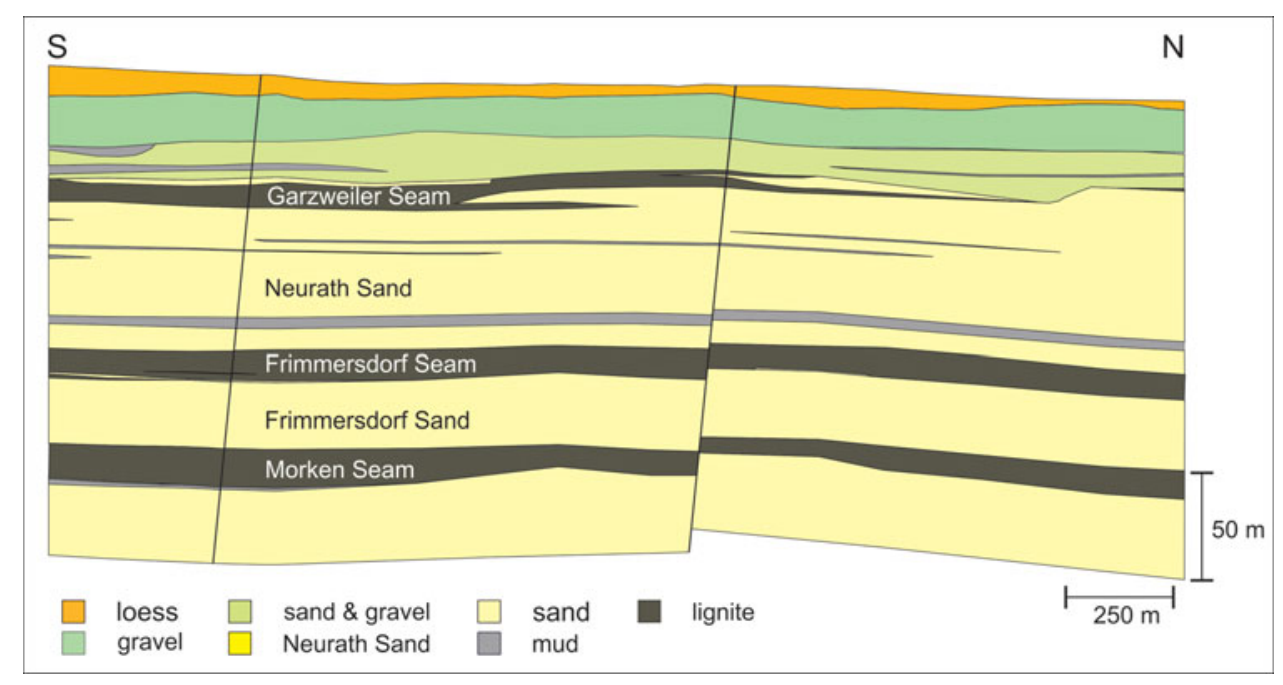

Fig. 10. Cross section of the Ville Formation from the Garzweiler open-cast mine (W of the measured profiles), interpreted from exploration drillings and geophysical well logs (RWE Power AG). The cross section comprises the northernmost extent of the Garzweiler Seam, as well as the laterally restricted sand bodies.

1999). Analyses carried out on stump horizons indicate that, at times, relatively dense conifer forests existed. These were mainly composed of Taxodiaceae and Pinaceae (with Sciadopitys as the most common genus), and subordinate palms (Mosbrugger et al., 1994). A detailed palaeovegetation analysis (based on palynology) carried out on the Garzweiler Seam in the Hambach open-cast mine provided the basis for a reconstruction of the vegetational succession of the seam (Huhn et al., 1997). A pine-ericalean pocosin-type vegetation, representing welldrained soil conditions, developed at the base of the seam, and was succeeded by scrub vegetation dominated by plant species of the Myrica, Betula and Cyrilla genera. In the upper part of the seam, a gradual transition to a Taxodium-Nyssa association was recorded, suggesting a change to a very high water table. Pollen analysis would suggest that angiosperm herbs did not play a significant role in the Garzweiler vegetation (Huhn et al., 1997). Organic petrological and organic geochemical analyses, carried out on samples from the Morken, Frimmersdorf and Garzweiler seams in the Garzweiler open-cast mine, suggested that the peat-forming vegetation of the coastal mires probably consisted of a combination of herbaceous-vegetated areas (Lücke et al., 1999; Stock et al., 2016).

The two lens-shaped sand intercalations within the Garzweiler Seam (FA5), separated by a thin lignite band, have been interpreted as a result of a regionally restricted inundation of the swamp environment at its northern boundary. The sand beds contain tidal bundles, which are typical for the shoreface environment below the low-tide level. Planar lamination, on the other hand, may indicate an intertidal depositional environment (i.e. high-energy laminites; see above). The finegrained nature of these deposits, however, would suggest a lowto moderate-energy setting. As these sand deposits are of limited regional extent (tens of metres; Fig. 10) they are inter- preted as representing a lagoonal or estuarine setting. To the north, the lens-shaped sand intercalations can be correlated with a cross-laminated, subaqueous (intertidal to subtidal) dune system (cross-lamination and tidal bundles in the upper part of profile 3). These represent either coast-parallel barrier sand bars (associated with barrier islands; i.e. wave breakers that protect the lagoonal milieu from the waves of the open sea; Fan, 2012) or, possibly, tidal sand bars (stream-parallel), which are characteristic of estuarine mouth areas (Dalrymple et al., 2012).

\section{Channel deposits}

Four characteristic beds containing black sand clasts were observed within the three measured profiles, and have been interpreted as channel deposits. The black sand clast-rich beds are interbedded with (trough) cross-laminated sands, which were deposited within a ridge-and-runnel system (e.g. Dabrio, 1982; Masselink \& Anthony, 2001). These beach-parallel sand ridges (i.e. longshore bars or dunes; Boersma, 1991; Fan, 2012; Reynaud \& Dalrymple, 2012) may be cut by rip channels (e.g. Aagaard et al., 1997; Haller, 2002; Castelle \& Coco, 2012) or tidal channels (e.g. Weimer et al., 1982; Lanzoni, 2002; Dalrymple \& Choi, 2007; Hughes, 2012). Both rip as well as tidal channels are considered to be important pathways for water-sediment exchange between the coastal and shelf environments (Aagaard et al., 1997; Fan, 2012; Hughes, 2012).

The erosionally bounded black sand beds and the associated intraformational (i.e. rip-up) clasts were deposited in tidal channels (Collinson et al., 2006). According to Hughes (2012), sand-dominated deposits in tidal channels represent the higherenergy periods of spring tides. Studies of tidal channels (mostly within intertidal environments; e.g. Lanzoni, 2002; Hughes, 2012), commonly note the presence of a coarse-sediment lag, 
including shells, wood fragments, mud clasts or pebbles, along the erosional bounding surface (Clifton, 1982; Hughes, 2012). These lag deposits may also include mud block breccias, which formed as a result of bank slumping or channel edge erosion (Terwindt, 1988; Hughes, 2012). Neither shells nor mud blocks are found in association with the intraformational sands in the Neurath Sand, the former having been dissolved by the passage of humic acids through the sand body, and the latter most probably did not form due to the lack of adjacent mud banks.

Tidal channels are commonly characterised by features produced as a result of tidal activity (e.g. reactivation surfaces, mud drapes in cross-sets, low-angle dipping cross-sets with alternating thicker and thinner packages of heterolithic sediments, flaser- and/or lenticular bedding or tidal bundles; de Raaf \& Boersma, 1971; Hughes, 2012). None of these, however, has been observed in the Neurath Sand channel deposits. The absence of characteristic features indicative of changing flow directions (ebb and flood currents) suggests deposition under unidirectional flow conditions (i.e. either ebb or flood). Additionally, the presence of wood remains, as well as the black humic substances, forming coats around each individual grain within the channel deposits (see above), suggests an ebb-dominated environment, with strong ebb currents transporting the humic substances as well as wood remains from the coastal mires into the intertidal and subtidal environments. However, tidal bundles within the surrounding subtidal deposits would suggest that both ebb and flood currents were generally strong enough for sand transport. Tide-generated channels can also be interpreted in terms of estuarine systems (Dalrymple \& Choi, 2007; and see below). These tide-generated swatchways separate elongate tidal sand bars at the transition from the estuary mouth to the marine setting (Dalrymple et al., 2012).

Another possible explanation for the formation of channels within this depositional environment may be related to rip currents. These offshore-directed currents are the result of seaward return flows through narrow channels between sand bars, and are induced by the backwash of waves (Aagaard et al., 1997). The infill of channels may occur as a result of channel migration or decreasing wave energy (Aagaard et al., 1997). However, rip currents are restricted to the intertidal environment (Masselink \& Hegge, 1995; Aagaard et al., 1997; Castelle \& Coco, 2012) and can thus only be regarded as responsible for the formation of the sand-clast beds within the breaker zone.

The unidirectional flow conditions within the black sandclast beds, the presence of humic substances, chert pebbles and wood fragments may all also be interpreted in terms of a single high-energy flow event. According to Hunt et al. (2015), erosion of sediments within the intertidal environment only occurs when tidal currents are reinforced by increased wave or wind energy. Studies of recent rip channels have noted that their initial formation can occur as a result of storms (Aagaard et al., 1997). Additionally, channel migration and channel infill have been observed after storm events (e.g. Castelle \& Coco, 2012). Dur- ing such events, increased wave energy can lead to extensive erosion of the coastal area (e.g. Russell, 1993; Eisma, 1998), followed by the distribution of backshore deposits into the marine setting through tidal channels and rip currents. However, the absence of hummocky cross-stratification (generally characteristic of storm-induced sedimentation, and completely absent throughout the Lower Rhine Basin) might suggest an absence of storm activity. On the other hand, the presence of Groden bedding (which forms as a result of storm surges inundating coastal marshes; Boersma, 1991; Schäfer et al., 2004; Bungenstock \& Schäfer, 2009; Schäfer, 2010) in the underlying Frimmersdorf Sand would suggest that storm deposition did indeed occur within the Lower Rhine Basin. Additionally, hummocky cross-stratification may be deformed or destroyed due to tides or storm wave activity (Eyles \& Clark, 1986).

As noted above, flow velocities within rip currents generated by the backwash of waves can be increased/reinforced by tidal currents, in particular by seaward-directed ebb currents (Aagaard et al., 1997). The deposits of the Neurath Sand show both the distinct influence of wave activity and the impact of tides. Therefore, both waves and tides (i.e. rip currents and tidal or estuarine currents) may have been responsible for the formation of the observed channel deposits.

\section{Depositional environment: tidal delta vs estuary}

The broader depositional setting of the Neurath Sand is problematic. In general, the Lower Rhine Basin in Miocene times formed an embayment, bounded by the uplifting Rhenish Massif in the SE and SW, and extending into the North Sea Basin in the NW (e.g. Schäfer et al., 1996; Lücke et al., 1999; Klett et al., 2002).

Two sources of clastic sediment input have been identified from the Lower Rhine Basin (Hager, 1993). The first, providing fine-grained quartz sands, was located in the SW North Sea, and the sediments were transported by coastal longshore currents (Breddin, 1932; Hager, 1993) following their deposition in the Lower Rhine Basin. The presence of large sand dunes and tidal bundles within the Neurath Sand provides unequivocal evidence for tidal and wave activity within the shallow-marine environment. The tidal range within the Miocene-age North Sea has been estimated at 2-4 m (mesotidal; Schäfer \& Utescher, 2014), although both tidal range and wave height can increase as a result of funnelling within embayments (e.g. estuaries or tidal inlets; Mazumder \& Arima, 2005; Dalrymple \& Choi, 2007; Longhitano et al., 2012).

The second sediment source was located to the SE (i.e. Rhenish Massif), with sediment transported by medium- to lowenergy fluvial systems entering the Lower Rhine Basin (Hager, 1993). It is probable that the Rhenish Massif in Miocene times was dewatered by several small river streams (compared to the present-day fluvial system within the Lower Rhine Basin). Peat accumulation of the Main Seam (i.e. the combined Morken, Frimmersdorf and Garzweiler Seams in the SE) took place on the 
banks of one of these systems, extending through the centre of the basin (Zagwijn \& Hager, 1987). This river system, interpreted as a precursor of the present-day river Sieg (Hager, 1993), subsequently shifted its location to the SW (Zagwijn \& Hager, 1987).

It has been suggested that a deltaic depositional environment formed at the entry point of the various fluvial systems (Boersma, 1991; Hager, 1993), based on the presence of a number of small to medium river systems, as well as the Rhenish Massif representing the provenance area. However, as described within this study, features that would represent characteristic deltaic deposits are not present within the Neurath Sand and, thus, such a model does not conform to the observations. Schäfer et al. (1996) have suggested that the sediments of the Neurath Sand were deposited in an estuarine system. Such a system develops in a transgressive setting (e.g. Dalrymple et al., 1992; Dalrymple, 2006; Dalrymple \& Choi, 2007), followed by the infill of the estuarine channels during progradation of the shoreline (Dalrymple et al., 2012). As noted above, the Serravallianage North Sea transgressed onto the peat accumulation of the present-day Frimmersdorf Seam, and the lowermost part of the Neurath Sand (i.e. FA1a, FA2) was subsequently deposited in a deepening marine setting (i.e. transgressive). Subsequent regression of the North Sea (FA1b, c - FA5) resulted in the deposition of a progradational shoreline sequence. Studies on recent and ancient estuarine systems have shown that infilling estuaries form features which are transitional with deltas (Dalrymple et al., 2012). Within the Lower Rhine Basin, the deposits of the Garzweiler Seam, and particularly of the overlying Inden Formation, mark the transition from a probable estuarine system (Neurath Sand) to a fluvial to deltaic system formed by the early Rhine river, which initially entered the Lower Rhine Basin in Tortonian times (Boenik, 2002; Sissingh, 2006; Kemna, 2008; Westerhoff et al., 2008). As such, the Neurath Sand could possibly be interpreted in terms of the estuarine model.

This model is confirmed by the presence of channel deposits (i.e. the black sand clasts), tidal bundles and sand dunes. The channel deposits, represented by the black sand-clast beds, probably represent swatchways, separating elongate tidal sand bars (Dalrymple et al., 2012). The cross-laminated/-bedded dune deposits of the sub- to intertidal settings of the Neurath Sand are interpreted as subtidal and intertidal sand bars, which are ubiquitous in the funnel-shaped mouth areas of estuaries (Dalrymple et al., 1992, 2012). The orientation of the cross-laminated dunes, however, could not be measured (due to the outcrop situation), so it is not possible to distinguish between coast-parallel orientated dunes (ridge-and-runnel systems, Dabrio 1982; Masselink \& Anthony 2001) and tidal sand bars (estuary, Dalrymple et al., 1992), which are orientated mainly stream-parallel (and, therefore, broadly perpendicular to the coastline; Dalrymple et al., 2012). The lens-shaped sand intercalations within the Garzweiler Seam, as noted above, provide evidence of tidedominated sand deposition within restricted areas of the mire, which may also be indicative of an estuarine origin (Dalrymple et al., 1992, 2012). In contrast to modern and ancient estuaries (e.g. Bostock et al., 2007; Dalrymple \& Choi, 2007; Choi, 2010; Uncles, 2010; Dalrymple et al., 2012), however, there was no major fluvial system entering the Lower Rhine Basin in Miocene times, but several small river systems, dewatering the adjacent Rhenish Massif and the adjacent coastal mires (Zagwijn \& Hager, 1987; Hager, 1993).

\section{Conclusions}

The Serravallian-age Neurath Sand is interpreted in terms of a characteristic shoreline succession within a tide- and wavedominated embayment. The transgression of the North Sea resulted in the deposition of subtidal deposits covering the peat accumulations of the present-day Frimmersdorf Seam, followed by mud-rich sediments of the transition zone as a result of increasing water depth. Subsequently, regressive conditions resulted in the deposition of a sequence of subtidal, intertidal and supratidal sediments and finally the re-establishment of coastal mires (present-day Garzweiler Seam). Lens-shaped sand intercalations within the Garzweiler Seam, which comprise tidal bundles and are bounded by subaquatic sand dunes in the $\mathrm{N}$, have probably been deposited in an estuarine or lagoonal milieu.

The interaction of wave and tidal currents with river systems, entering the Lower Rhine Basin from the adjacent Rhenish Massif, and also dewatering the peat accumulations of the presentday Main Seam in the S, are indicative of an estuarine system. The estuarine system was formed by several comparably small rivers, flanked by coastal mires and marshes in the SE, which laterally passed into tidal mudflats, and, with increasing water depth to the NW, foreshore and shoreface environments in the centre of the Lower Rhine Basin.

\section{Acknowledgements}

We acknowledge the funding for this study from RWE Power AG. Thanks to the staff members of the department GOC-L, especially the field crew of the Garzweiler open-cast mine, as well as Ulrich Krüger and Horst Hassel for editing datasets. The manuscript benefited greatly from the comments of Wim Westerhoff, Marinus Eric Donselaar and an anonymous reviewer.

\section{References}

Aagaard, T. \& Hughes, M.G., 2006. Sediment suspension and turbulence in the swash zone of dissipative beaches. Marine Geology 228: 117-135.

Aagaard, T., Greenwood, B. \& Nielsen, J., 1997. Mean currents and sediment transport in a rip channel. Marine Geology 140: 25-45.

Albers, H.J. \& Felder, W.M., 1981. Feuersteingerölle im Oligomiozän der Niederrheinischen Bucht als Ergebnis mariner Abrasion und Carbonatlösungsphasen auf der Kreide-Tafel von Aachen-Südlimburg. In: Reiche, E. \& Hilden, H.D. 
(eds): Geologie und Lagerstättenerkundung im Rheinischen Braunkohlenrevier. Fortschritte in der Geologie von Rheinland und Westfalen 29: 469-482.

Alert, S.P., 1974. Systematic review of the genus Skolithos. Journal of Paleontology 48(4): 661-669.

Archer, A.W., 1996. Reliability of lunar orbital periods extracted from ancient cyclic tidal rhythmites. Earth and Planetary Science Letters 141: 1-10.

Bartholdy, J., 2012. Salt marsh sedimentation. In: Davis, R.A., Jr \& Dalrymple, R.W. (eds): Principles of tidal sedimentology. Springer (Berlin): 151-185.

Becker, B. \& Asmus, S., 2005. Beschreibung und Korrelation der känozoischen Lockergesteinsschichten der Grundgebirgsbohrungen im Umfeld des Tagebaus Hambach. In: Der tiefere Untergrund der Niederrheinischen Bucht. Ergebnisse eines Tiefbohrprogramms im Rheinischen Braunkohlenrevier. Scriptum 13: $61-74$.

Berggren, W.A., Kent, D.V., Swisher, C.C., III \& Aubry, M.-P., 1995. A revised Cenozoic geochronology and chronostratigraphy. In: Berggren, W.A., Kent, D.V., Aubry, M.-P. \& Hardenbol, J. (eds): Geochronology, time scales and global stratigraphic correlation. SEPM Special Publication 54: 129-212.

Boenik, W., 2002. The Pleistocene drainage pattern in the Lower Rhine Basin. Netherlands Journal of Geosciences / Geologie en Mijnbouw 81(2): 201-210.

Boersma, J.R., 1991. A large flood-tidal delta and its successive spill-over apron: detailed proximal-distal facies relationships (Miocene Lignite Suite, Lower Rhine Embayment, Germany). In: Smith, D.G., Reinson, G.E, Zaitlin, B.A. \& Rahmani, R.A. (eds): Clastic tidal sedimentology. Canadian Society of Petroleum Geologists Memoir 16 (Calgary): 227-252.

Bostock, H.C., Brooke, B.P., Ryan, D.A., Hancock, G., Pietsch, T., Packett, R. $\&$ Harle, K., 2007. Holocene and modern sediment storage in the subtropical macrotidal Fitzroy River estuary, Southeast Queensland, Australia. Sedimentary Geology 201: 321-340.

Breddin, H., 1932. Die Feuersteingerölle im Niederrheinischen Tertiär, ein Beweis für die paralische Natur der Braunkohlenflöze. Centralblatt für Mineralogie, Geologie und Paläontologie B: 395-404.

Bromley, R.G., 1996. Trace fossils: biology, taphonomy and applications. Taylor \& Francis (Abingdon, 0xon, \& New York): $361 \mathrm{pp.}$

Bungenstock, F. \& Schäfer, A., 2009. The Holocene relative sea-level curve for the tidal basin of the barrier island Langeoog, German Bight, Southern North Sea. Global and Planetary Change 66: 34-51.

Castelle, B. \& Coco, G., 2012. The morphodynamics of rip channels on embayed beaches. Continental Shelf Research 43: 10-23.

Choi, $K .$, 2010. Rhythmic climbing-ripple cross-lamination in inclined heterolithic stratification (IHS) of a macrotidal estuarine channel, Gomso Bay, West Coast of Korea. Journal of Sedimentary Research 80(6): 550-561.

Clifton, H.E., 1981. Progradational sequences in Miocene shoreline deposits, southeastern Caliente Range, California. Journal of Sedimentary Petrology 51(1): 165-184.

Clifton, H.E., 1982. Estuarine deposits. In: Scholle, P.A. \& Spearing, D. (eds): Sandstone depositional environments. AAPG Memoir 31: 179-189.

Collinson, J., Mountney, N. \& Thomson, D., 2006. Sedimentary structures. Terra Publishing (Edinburgh): $292 \mathrm{pp}$.

Crimes, T.P., 1977. Trace fossils of an Eocene deep-sea fan, northern Spain. In: Crimes, T.P. \& Harper, J.C. (eds): Trace fossils 2. Seel House Press (Liverpool): 71-90.
Curran, H.A. \& Frey, R.W., 1977. Pleistocene trace fossils from North Carolina (USA), and their Holocene analogues. In: Crimes, T.P. \& Harper, J.C. (eds): Trace fossils 2. Seel House Press (Liverpool): 139-162.

Dabrio, C.J., 1982. Sedimentary structures generated on the foreshore by migrating ridge and runnel systems on microtidal and mesotidal coasts of S. Spain. Sedimentary Geology 32: 141-151.

Dalrymple, $R$.W., 2006. Incised valleys in time and space: an introduction to the volume and an examination of the controls on valley formation and filling. In: Dalrymple, R.W., Leckie, D.A. \& Tillman, R.W. (eds): Incised valleys in time and space. SEPM Special Publication 85: 5-12.

Dalrymple, R.W. \& Choi, K., 2007. Morphologic and facies trends through the fluvial-marine transition in tide-dominated depositional systems: a schematic framework for environmental and sequence-stratigraphic interpretation. Earth-Science Reviews 81: 135-174.

Dalrymple, R.W., Zaitlin, B.A. \& Boyd, R., 1992. Estuarine facies models: conceptual basis and stratigraphic implications: perspective. Journal of Sedimentary Petrology 62(6): 1130-1146.

Dalrymple, R.W., Mackay, D.A., Ichaso, A.A. \& Choi, K.S., 2012. Processes, morphodynamics, and facies of tide-dominated estuaries. In: Davis, R.A., Jr \& Dalrymple, R.W. (eds): Principles of tidal sedimentology. Springer (Berlin): 79107.

Darscheid, E., 1981. Wurzelböden und Flözbasis in der rheinischen Braunkohle. In: Reiche, E. \& Hilden, H.D. (eds): Geologie und Lagerstättenerkundung im Rheinischen Braunkohlenrevier. Fortschritte in der Geologie von Rheinland und Westfalen 29: 165-175.

De Raaf, J. \& Boersma, J.R., 1971. Tidal deposits and their sedimentary structures. Geologie en Mijnbouw 50(3): 479-504.

Desjardins, P.R., Mángano, M.G., Buatois, L.A. \& Pratt, B.R., 2010. Skolithos pipe rock and associated ichnofabrics from the southern Rocky Mountains, Canada: colonization trends and environmental controls in an early Cambrian sand-sheet complex. Lethaia 43: 507-528.

Eisma, D., 1998. Intertidal deposits: river mouths, tidal flats, and coastal lagoons. CRC Press (Boca Raton, FL): 527 pp.

Eyles, N. \& Clark, B.M., 1986. Significance of hummocky and swaley crossstratification in late Pleistocene lacustrine sediments of the Ontario basin, Canada. Geology 14: 679-682.

Fan, D., 2012. Open-coast tidal flats. In: Davis, R.A., Jr \& Dalrymple, R.W. (eds): Principles of tidal sedimentology. Springer (Berlin): 187-229.

Figueiral, I., Mosbrugger, V., Rowe, N.P., Ashraf, A.R., Utescher, T. \& Jones, T.P., 1999. The Miocene peat-forming vegetation of northwestern Germany: an analysis of wood remains and comparison with previous palynological interpretations. Review of Palaeobotany and Palynology 104: 239-266.

Folk, R.L., 1974. Petrology of sedimentary rocks. Hempill Publishing Company (Austin, TX): $182 \mathrm{pp}$.

Frey, R.W., 1990. Trace fossils and hummocky cross-stratification, Upper Cretaceous of Utah. Palaois 5(3): 203-218.

Frey, R.W., Howard, J.D. \& Pryor, W.A., 1978. Ophiomorpha: its morphologic, taxonomic, and environmental significance. Palaeogeography, Palaeoclimatology, Palaeoecology 23: 199-229.

Geluk, M.C., Duin, E.J.T., Dusar, M., Rijkers, R.H.B., van den Berg, M.W. \& van Rooijen, P., 1994. Stratigraphy and tectonics of the Roer Valley Graben. Geologie en Mijnbouw 73: 129-141. 
Graham, D.J. \& Midgley, N.G., 2000. Technical Communication. Graphical representation of particle shape using triangular diagrams: an Excel spreadsheet method. Earth Surface Processes and Landforms 25: 1473-1477.

Grützner, C., Fischer, P. \& Reicherter, K., 2016. Holocene surface ruptures of the Rurrand Fault, Germany - insights from palaeoseismology, remote sensing and shallow geophysics. Geophysical Journal International 204: 1662-1677.

Hager, H., 1986. Peat accumulation and syngenetic clastic sedimentation in the Tertiary of the Lower Rhine Basin (F.R. Germany). Mémoires de la Société Géologique de France 149: 51-56.

Hager, H., 1993. The origin of the Tertiary lignite deposits in the Lower Rhine region, Germany. International Journal of Coal Geology 23: 251-262.

Haller, M.C., 2002. Experimental study of nearshore dynamics on a barred beach with rip channels. Journal of Geophysical Research 107: 14-1-14-21.

Haq, B.U., Hardenbol, J. \& Vail, P.R., 1987. Chronology of fluctuating sea levels since the Triassic. Science 235: 1156-1167.

Haq, B.U., Hardenbol, J. \& Vail, P.R., 1988. Mesozoic and Cenozoic chronostratigraphy and cycles of relative sea level change. In: Wilgus, C.K., Hastings, B.S., Kendall, G.C.St.C., Posamentier, H.W., Ross, C.A. \& van Wagoner, J.C. (eds): Sea-level changes: an integrated approach. SEPM Special Publication 42: 71108.

Hardenbol, J., Thierry, J., Farley, M.B., Jacquin, T., de Graciansky, C. \& Vail, P.R., 1998. Mesozoic-Cenozoic sequence chronostratigraphy of European basins. In: Graciansky, P.C. de, Hardenbol, J., Jacquin, T. \& Vail, P.R. (eds): Mesozoic and Cenozoic sequence stratigraphy of European basins. SEPM Special Publication No. 60: 84.

Hinzen, K.-G., 2003. Stress field in the Northern Rhine area, Central Europe, from earthquake fault plane solutions. Tectonophysics 377: 325-356.

Hiscott, R.N., James, N.P. \& Pemberton, S.G., 1984. Sedimentology and ichnology of the Lower Cambrian Bradore Formation, coastal Labrador: fluvial to shallowmarine transgressive sequence. Bulletin of Canadian Petroleum Geology 32(1): 11-26.

Hori, K., Saito, Y., Zhao, Q., Cheng, X., Wang, P., Sato, Y. \& Li, C., 2001. Sedimentary facies of the tide-dominated paleo-Changjiang (Yangtze) estuary during the last transgression. Marine Geology 177: 331-351.

Houtgast, R.F. \& van Balen, R.T., 2000. Neotectonics of the Roer Valley Rift System, the Netherlands. Global and Planetary Change 27: 131-146.

Hovikoski, J., Räsänen, M., Gingras, M., Roddaz, M., Brusset, S., Hermoza, W. Pittman, L.R. \& Lertola, K., 2005. Miocene semidiurnal tidal rhythmites in Madre de Dios, Peru. Geology 33(3): 177-180.

Howard, J.D. \& Frey, R.W., 1984. Characteristic trace fossils in nearshore to offshore sequences, Upper Cretaceous of east-central Utah. Canadian Journal of Earth Sciences 21(2): 200-219.

Hughes, Z.J., 2012. Tidal channels on tidal flats and marshes. In: Davis, R.A., Jr \& Dalrymple, $R$.W. (eds): Principles of tidal sedimentology. Springer (Berlin): 269-300.

Huhn, B., Utescher, T., Ashraf, A.R. \& Mosbrugger, V., 1997. The peat-forming vegetation in the Middle Miocene Lower Rhine Embayment: an analysis based on palynological data. Mededelingen Nederlands Instituut voor Toegepaste Geowetenschappen 58: 211-218.

Hunt, S., Bryan, K.R. \& Mullarney, J.C., 2015. The influence of wind and waves on the existence of stable intertidal morphology in meso-tidal estuaries. Geomorphology 228: 158-174.
Kemna, H.A., 2008. Pliocene and Lower Pleistocene fluvial history of the Lower Rhine Embayment, Germany: examples of the tectonic forcing of river courses. Quaternary International 189: 106-114.

Klett, M., Eichhorst, F. \& Schäfer, A., 2002. Facies interpretation from well logs applied to the Tertiary Lower Rhine Basin fill. In: Schäfer, A. \& Siehl, A. (eds): Rift tectonics and syngenetic sedimentation - the Cenozoic Lower Rhine Graben and related structures. Netherlands Journal of Geosciences 81(2): 167176.

Kroon, A. \& Masselink, G., 2002. Morphodynamics of intertidal bar morphology on a macrotidal beach under low-energy wave conditions, North Lincolnshire, England. Marine Geology 190: 591-608.

Kvale, E.P., 2012. Tidal constituents of modern and ancient tidal rhythmites: criteria for recognition and analyses. In: Davis, R.A., Jr \& Dalrymple, R.W. (eds): Principles of tidal sedimentology. Springer (Berlin): 1-17.

Lanzoni, S., 2002. Long-term evolution and morphodynamic equilibrium of tidal channels. Journal of Geophysical Research 107: 1-1-1-13.

Le Hir, P., Roberts, W., Cazaillet, 0., Christie, M., Bassoullet, P. \& Bacher, C., 2000. Characterization of intertidal flat hydrodynamics. Continental Shelf Research 20: 1433-1459.

Longhitano, S.G., Mellere, D., Steel, R.J. \& Ainsworth, R.B., 2012. Tidal depositional systems in the rock record: a review and new insights. Sedimentary Geology 279: 2-22.

Lücke, A., Helle, G., Schleser, G.H., Figueiral, I., Mosbrugger, V., Jones, T.P. \& Rowe, N.P., 1999. Environmental history of the German Lower Rhine Embayment during the Middle Miocene as reflected by carbon isotopes in brown coal. Palaeogeography, Palaeoclimatology, Palaeoecology 154: 339-352.

MacEachern, J.A., Bann, K.L., Gingras, M.K., Zonneveld, J.-P., Dashtgard, S.E. \& Pemberton, S.G., 2012. The ichnofacies paradigm. In: Knaust, D. \& Bromley, R.G. (eds): Trace fossils as indicators of sedimentary environments 64. Elsevier (Amsterdam): 103-138.

Masselink, G. \& Anthony, E.J., 2001. Location and height of intertidal bars on macrotidal ridge and runnel beaches. Earth Surface Processes and Landforms 26: 759-774.

Masselink, G. \& Hegge, B., 1995. Morphodynamics of meso- and macrotidal beaches: examples from central Queensland, Australia. Marine Geology 129: $1-23$.

Masselink, G. \& Puleo, J.A., 2006. Swash-zone morphodynamics. Continental Shelf Research 26: 661-680.

Mazumder, R. \& Arima, M., 2005. Tidal rhythmites and their implications. EarthScience Reviews 69: 79-95.

Michon, L., van Balen, R.T., Merle, 0. \& Pagnier, H., 2003. The Cenozoic evolution of the Roer Valley Rift System integrated at a European scale. Tectonophysics 367: 101-126.

Mosbrugger, V., Gee, C.T., Belz, G. \& Ashraf, A.R., 1994. Three-dimensional reconstruction of an in-situ Miocene peat forest from the Lower Rhine Embayment, northwestern Germany - new methods in palaeovegetation analysis. Palaeogeography, Palaeoclimatology, Palaeoecology 110: 295-317.

Mosbrugger, V., Utescher, T. \& Dilcher, D.L., 2005. Cenozoic continental climatic evolution of Central Europe. Proceedings of the National Academy of Sciences of the United States of America 102(42): 14,964-14,969.

Munsterman, D.K. \& Brinkhuis, H., 2004. A southern North Sea Miocene dinoflagellate cyst zonation. Netherlands Journal of Geosciences / Geologie en Mijnbouw 83(4): 267-285. 
Otvos, E.G., 2000. Beach ridges - definitions and significance. Geomorphology 32: 83-108.

Pemberton, S.G. \& Frey, R.W., 1984. Ichnology of storm-influenced shallow marine sequence: Cardium Formation (Upper Cretaceous) at Seebe, Alberta. In: Stott, D.F. \& Glass, D.J. (eds): The Mesozoic of Middle North America: a selection of papers from the symposium on the Mesozoic of Middle North America, Calgary, Alberta, Canada. Canadian Society of Petroleum Geologists Memoir 9: 281-304.

Petzelberger, B., 1994. Die marinen Sande im Tertiär der südlichen Niederrheinischen Bucht. Sedimentologie, Fazies und stratigraphische Deutung unter Berücksichtigung der Sequenzstratigraphie. Bonner Geowissenschaftliche Schriften 14: 1-112.

Rasser, M.W., Harzhauser, M., Anistratenko, O.Y., Anistratenko, V.V., Bassi, D., Belak, M., Berger, J.-P., Bianchini, G., Cičić, S., Ćosović, V., Doláková, N., Drobne, K., Filipescu, S., Gürs, K., Hladilová, Š., Hrvatović, H., Jelen, B., Kasiński, J.R., Kováč, M., Kralj, P., Marjanac, T., Márton, E., Mietto, P., Moro, A., Nagymarosy, A., Nebelsick, J.H., Nehyba, S., Ogorelec, B., Oszczypko, N., Pavelić, D., Pavlovec, R., Pavšič, J., Petrová, P., Piwocki, M., Poljak, M., Pugliese, N., Redžepović, Rifelj, H., Roetzel, R., Skaberne, D., Sliva, L., Standke, G., Tunis, G., Vass, D. \& Wagreich, M. \& Wesselingh, F., 2008. Palaeogene and Neogene. In: McCann, T. (ed.): The geology of Central Europe. Mesozoic and Cenozoic. The Geological Society (London): 1031-1139.

Reesink, A.J.H. \& Bridge, J.S., 2007. Influence of superimposed bedforms and flow unsteadiness on formation of cross strata in dunes and unit bars. Sedimentary Geology 202: 281-296.

Reicherter, K., Froitzheim, N., Jarosiński, M., Badura, J., Franzke, H.-J., Hansen, M., Hübscher, C., Müller, R., Poprawa, P., Reinecker, J., Stackebrandt, W., Voigt, T., Eynatten, H. von \& Zuchiewicz, W., 2008. Alpine tectonics north of the Alps. In: McCann, T. (ed.): The geology of Central Europe. Mesozoic and Cenozoic. The Geological Society (London): 1233-1285.

Reynaud, J.-Y. \& Dalrymple, R.W., 2012. Shallow-marine tidal deposits. In: Davis, R.A., Jr \& Dalrymple, R.W. (eds): Principles of tidal sedimentology. Springer: 335-369.

Russell, P.E., 1993. Mechanisms for beach erosion during storms. Continental Shelf Research 13(11): 1243-1265.

Schäfer, A., 2010. Klastische Sedimente. Fazies und Sequenzstratigraphie. Springer (Heidelberg): $416 \mathrm{pp}$.

Schäfer, A. \& Utescher, T., 2014. Origin, sediment fill, and sequence stratigraphy of the Cenozoic Lower Rhine Basin (Germany) interpreted from well logs. Zeitschrift der Deutschen Gesellschaft für Geowissenschaften 165(2): 287-314.

Schäfer, A., Hilger, D., Gross, G. \& von der Hocht, F., 1996. Cyclic sedimentation in Tertiary Lower-Rhine Basin (Germany) - the 'Liegendrücken' of the browncoal open-cast Fortuna mine. Sedimentary Geology 103: 229-247.

Schäfer, A., Utescher, T. \& Mörs, T., 2004. Stratigraphy of the Cenozoic Lower Rhine Basin, northwestern Germany. Newsletters on Stratigraphy 40(1/2): 73110.

Schäfer, A., Utescher, T., Klett, M. \& Valdivia-Manchego, M., 2005. The Cenozoic Lower Rhine Basin - rifting, sedimentation, and cyclic stratigraphy. International Journal of Earth Sciences 94: 621-639.

Schneider, H. \& Thiele, S., 1965. Geohydrologie des Erftgebiets. Ministerium für Ernährung, Landwirtschaft und Forsten, Nordrhein-Westfalen (Düsseldorf): $185 \mathrm{pp}$.
Schumacher, M.E., 2002. Upper Rhine Graben. Role of preexisting structures during rift evolution. Tectonics 21(1): 6-1-6-17.

Seilacher, $\boldsymbol{A} .$, 1964. Sedimentological classification and nomenclature of trace fossils. Sedimentology 3: 253-256.

Sissingh, W., 2003. Tertiary paleogeographic and tectonostratigraphic evolution of the Rhenish Triple Junction. Palaeogeography, Palaeoclimatology, Palaeoecology 196: 229-263.

Sissingh, W., 2006. Syn-kinematic palaeogeographic evolution of the West European Platform: correlation with Alpine plate collision and foreland deformation. Netherlands Journal of Geosciences / Geologie en Mijnbouw 85(2): 131-180.

Stive, M.J.F., Aarninkhof, S.G.J., Hamm, L., Hanson, H., Larson, M., Wijnberg, K.M., Nicholls, R.J. \& Capobianco, M., 2002. Variability of shore and shoreline evolution. Coastal Engineering 47: 211-235.

Stock, A.T., Littke, R., Zieger, L. \& Thielemann, T., 2016. Miocene depositional environment and climate in western Europe: the lignite deposits of the Lower Rhine Basin, Germany. International Journal of Coal Geology 175: 2-18.

Stupples, P., 2002. Tidal cycles preserved in late Holocene tidal rhythmites, the Wainway Channel, Romney Marsh, southeast England. Marine Geology 182: 231-246.

Suhr, P., 1982. Ophiomorpha nodosa LUNDGREN 1891 im Miozän der Lausitz. Abhandlungen des Staatlichen Museums für Mineralogie und Geologie 31: 173176.

Suhr, P., 1989. Beiträge zur Ichnologie des Niederlausitzer Miozäns. Freiberger Forschungshefte C436: 93-101.

Taylor, A.M. \& Goldring, R., 1993. Description and analysis of bioturbation and ichnofabric. Journal of the Geological Society 150(1): 141-148.

Teichmüller, M., 1958. Rekonstruktion verschiedener Moortypen des Hauptflözes der niederrheinischen Braunkohle. In: Ahrens, W. (ed.): Die Niederrheinische Braunkohlenformation. Fortschritte in der Geologie von Rheinland und Westfalen 2: 599-612.

Teichmüller, $R .$, 1958. Die Niederrheinische Braunkohlenformation. Stand der Untersuchungen und offene Fragen. In: Ahrens, W. (ed.): Die Niederrheinische Braunkohlenformation. Fortschritte in der Geologie von Rheinland und Westfalen 2: 721-750.

Terwindt, J., 1988. Palaeo-tidal reconstructions of inshore tidal depositional environments. In: de Boer, P.L., van Gelder, A. \& Nio, S.D. (eds): Tide-influenced sedimentary environments and facies. D. Reidel Publishing Company (Dordrecht): 233-263.

Tessier, B., Archer, A.W., Lanier, W.P. \& Feldman, H.R., 1995. Comparison of ancient tidal rhythmites (Carboniferous of Kansas and Indiana, USA) with modern analogues (the Bay of Mont-Saint-Michel, France). In: Flemming, B.W. \& Bartholomä, A. (eds): Tidal signatures in modern and ancient sediments. Special Publication of the International Association of Sedimentologists 24: 259-271.

Tonkin, N.S., McIlroy, D., Meyer, R. \& Moore-Turpin, A., 2010. Bioturbation influence on reservoir quality: a case study from the Cretaceous Ben Nevis Formation, Jeanne d'Arc Basin, offshore Newfoundland, Canada. AAPG Bulletin 94(7): 1059-1078.

Tucker, M.E., 2003. Sedimentary rocks in the field. John Wiley \& Sons Ltd (Chichester): $236 \mathrm{pp}$. 
Uchman, A. \& Demircan, H., 1999. Trace fossils of Miocene deep-sea fan fringe deposits from the Cingöz Formation, southern Turkey. Annales Societatis Geologorum Poloniae 69: 125-135.

Uncles, R.J., 2010. Physical properties and processes in the Bristol Channel and Severn Estuary. Marine Pollution Bulletin 61: 5-20.

Utescher, T., Mosbrugger, V., Ivanov, D. \& Dilcher, D.L., 2009. Present-day climatic equivalents of European Cenozoic climates. Earth and Planetary Science Letters 284: 544-552.

Utescher, T., Ashraf, A.R., Dreist, A., Dybkjaer, K., Mosbrugger, V., Pross, J. \& Wilde, V., 2012. Variability of Neogene continental climates in Northwest Europe - a detailed study based on microfloras. Turkish Journal of Earth Sciences 21: $289-314$.

Van Balen, R.T., Houtgast, R.F. \& Cloetingh, S.A.P.L., 2005. Neotectonics of the Netherlands: a review. Quaternary Science Reviews 24 (3-4): 439-454.

Van der Burgh, J., 1973. Hölzer der niederrheinischen Braunkohlenformation, 2. Hölzer der Braunkohlengruben 'Maria Theresia' zu Herzogenrath, 'Zukunft West' zu Eschweiler und 'Victor' (Zülpich Mitte) zu Zülpich. Nebst einer systematisch-anatomischen Bearbeitung der Gattung Pinus L. Review of Palaeobotany and Palynology 15: 73-275.

Vanneste, K., Meghraoui, M. \& Camelbeeck, T., 1999. Late Quaternary earthquake-related soft-sediment deformation along the Belgian portion of the Feldbiss Fault, Lower Rhine Graben system. Tectonophysics 309: 57-79.

Verbeek, J.W., de Leeuw, C.S., Parker, N. \& Wong, T.E., 2002. Characterisation and correlation of Tertiary seismostratigraphic units in the Roer Valley Graben. Netherlands Journal of Geosciences / Geologie en Mijnbouw 81(2): 159-166.

Visser, M.J., 1980. Neap-spring cycles reflected in Holocene subtidal large-scale bedforms deposits: a preliminary note. Geology 8: 543-546.

Von der Brelie, G. \& Wolf, M., 1981. 'Sequoia' und Sciadopitys in den Braunkohlenmooren der Niederrheinischen Bucht. In: Reiche, E. \& Hilden,
H.D. (eds): Geologie und Lagerstättenerkundung im Rheinischen Braunkohlenrevier. Fortschritte in der Geologie von Rheinland und Westfalen 29: 177-191.

Weimer, R.J., Howard, J.D. \& Lindsay, D.R., 1982. Tidal flats and associated tidal channels. In: Scholle, P.A. \& Spearing, D. (eds): Sandstone depositional environments. The American Association of Petroleum Geologists (Tulsa, 0K): 191-245.

Westerhoff, W.E., Kemna, H.A. \& Boenik, W., 2008. The confluence area of Rhine, Meuse, and Belgian rivers: Late Pliocene and Early Pleistocene fluvial history of the northern Lower Rhine Embayment. Netherlands Journal of Geosciences / Geologie en Mijnbouw 87(1): 107-125.

Wong, T.E., Parker, N. \& Horst, P., 2001. Tertiary sedimentary development of the Broad Fourteens area, the Netherlands. Netherlands Journal of Geosciences / Geologie en Mijnbouw 80(1): 85-94.

Yang, B.C., Dalrymple, R.W. \& Chun, S.S., 2005. Sedimentation on a wavedominated, open-coast tidal flat, south-western Korea: summer tidal flat winter shoreface. Sedimentology 52: 235-252.

Zagwijn, W.H. \& Hager, H., 1987. Correlations of continental and marine Neogene deposits in the south-eastern Netherlands and the Lower Rhine District. Mededelingen van de Werkgroep voor Tertiaire en Kwartaire Geologie 24(1-2): 59-78.

Ziegler, P.A., 1992. European Cenozoic rift system. In: Ziegler, P.A. (ed.): Geodynamics of rifting, volume 1 . Case history studies on rifts: Europe and Asia. Tectonophysics 208: 91-111.

Ziegler, P.A., 1994. Cenozoic rift system of Western and Central Europe: an overview. Geologie en Mijnbouw 73(2-4): 99-127.

Ziegler, P.A. \& Dèzes, P., 2007. Cenozoic uplift of Variscan Massifs in the Alpine foreland: timing and controlling mechanisms. Global and Planetary Change 58: 237-269. 